\title{
Evaluation of the Generation and Release of Flammable Gases in Tank 241-SY-101

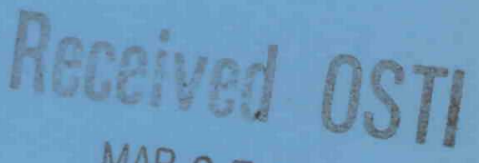 MAR 031992
}

Prepared for the U.S. Department of Energy Office of Environmental Restoration and Waste Management

\section{We Westinghouse Hanford Company Richland, Washington}

Hanford Operations and Engineering Contractor for the

U.S. Department of Energy under Contract DE-AC06-87RL10930

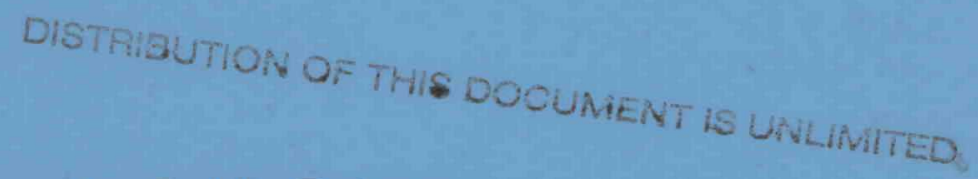




\section{LEGAL DISCLAIMER}

This report was prepared as an account of work sponsored by an agency of the United States Government. Neither the United States Government nor any agency thereof, nor any of their employees, nor any of their contractors, subcontractors or their employees, makes any warranty, express or implied, or assumes any legal liability or responsibility for the accuracy, completeness, or any third party's use or the results of such use of any information, apparatus, product, or process disclosed, or represents that its use would not infringe privately owned rights. Reference herein to any specific commercial product, process, or service by trade name, trademark, manufacturer, or otherwise, does not necessarily constitute or imply its endorsement, recommendation, or favoring by the United States Government or any agency thereof or its contractors or subcontractors. The views and opinions of authors expressed herein do not necessarily state or reflect those of the United States Government or any agency thereof.

This report has been reproduced from the best available copy. Available in paper copy and microfiche.

Available to the U.S. Department of Energy and its contractors from

Office of Scientific and Technical Information P. O. Box 62

Oak Ridge, TN 3783

(615) $576-8401$

Available to the public from the U.S. Department of Commerce National Technical Information Service

5285 Port Royal Road

Springfield, VA 2216

(703) $487-4650$

Printed in the United States of America

DISCLM-1.CHP (1-91) 


\section{DISCLAIMER}

This report was prepared as an account of work sponsored by an agency of the United States Government. Neither the United States Government nor any agency Thereof, nor any of their employees, makes any warranty, express or implied, or assumes any legal liability or responsibility for the accuracy, completeness, or usefulness of any information, apparatus, product, or process disclosed, or represents that its use would not infringe privately owned rights. Reference herein to any specific commercial product, process, or service by trade name, trademark, manufacturer, or otherwise does not necessarily constitute or imply its endorsement, recommendation, or favoring by the United States Government or any agency thereof. The views and opinions of authors expressed herein do not necessarily state or reflect those of the United States Government or any agency thereof. 


\section{DISCLAIMER}

Portions of this document may be illegible in electronic image products. Images are produced from the best available original document. 


\section{Evaluation of the Generation and Release of Flammable Gases in Tank 241-SY-101}

H. Babad

G. D. Johnson

J. A. Lechelt

D. A. Reynolds

Westingnouse Haniord Company

L. R. Pederson

D. M. Strachan

Pacific Northwest Lacoratory

D. Meisel

C. Jonah

Argonne National Laboratory

E. C. Ashby

Georgia Institute of Technology

Date Published

November 1991

Prepared for the U.S. Department of Energy Office of Environmental Restoration and Waste Management

(2) Westinghouse $\begin{aligned} & \text { P.O. Box }: 979 \\ & \text { Hanford Company } \\ & \text { Ficniand, Washington } 99352\end{aligned}$

maniord Coeracons and Engineenng Contracior ior the

U.S. Jeparment of Energy under Contract DE-ACO6-j̈TRL10930 
WHC-EP-0517

\title{
EVALUATION OF THE GENERATION AND RELEASE
} OF FLAMMABLE GASES IN TANK 241-SY-101

\begin{abstract}
Tank 241-5Y-101 is a double shell, high-level waste tank located in the 200 West Area of the Hanford Site. This tank contains about 1 million gallons of waste that was concentrated at the 242-S Evaporator. Shortly after the waste was put in the tank, the waste began to expand because the generation of gases. In 1990 this tank was declared to have an unreviewed safety question because of the periodic release of hydrogen and nitrous oxide.

A safety program was established to conduct a characterization of the waste and vented gases and to determine an effective means to prevent the accumulation of flammable gases in the tank dome space and ventilation system. Results of the expanded characterization conducted in fiscal year 1991 are presented. The use of gas chromatographs, mass spectrometers, and hydrogenspecific monitors provided a grater understanding of the vented gases. Additional instrumentation placed in the tank also helped to provide more detailed information on tank temperatures, gas pressure, and gas flow rates.
\end{abstract}

An extensive laboratory study involving the Westinghouse Hanford Company, Pacific Northwest Laboratory, Argonne National Laboratory, and the Georgia Institute of Technology was initiated for the purpose of determining the mechanisms responsible for the generation of various gases. These studies evaluate both radiolytic and thermochemical processes. Results of the first series of experiments are described. 
WHC-EP-0517

This page intentionally left blank. 
CONTENTS

1.0 INTROOUCTION . . . . . . . . . . . . . . . . . . 1

2.0 BACKGROUND INFORMATION ON TANK $241-5 \%-101 \ldots \ldots \ldots$

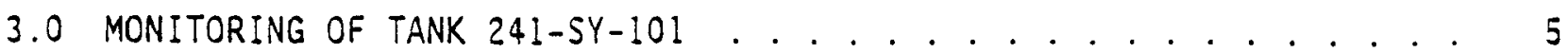

3.1 SURFACE LEVEL MEASUREMENTS . . . . . . . . . . . . . . . . . . 5

3.2 TANK PRESSURE . . . . . . . . . . . . . . . . . . . . 7

3.3 VENTILATION FLOW RATE. ........................ 7

3.4 GAS COMPOSITION . . . . . . . . . . . . . . . . . . . . . 7

3.5 TEMPERATURE MEASUREMENTS . . . . . . . . . . . . . . . . . . 9

4.0 SUMMARY OF GAS RELEASE EVENTS . . . . . . . . . . . . . . . . 10

4.1 GAS RELEASE EVENT OF APRIL $1990 \ldots \ldots$. . . . . . . . . . . . . 11

4.2 GAS RELEASE EVENT OF AUGUST $1990 \ldots \ldots$. . . . . . . . . . . . . . 11

4.3 GAS RELEASE EVENT OF OCTOBER 1990 . . . . . . . . . . . . . . . 14

4.4 GAS RELEASE EVENT OF FEBRUARY 1991 . . . . . . . . . . . . . . . 14

4.5 GAS RELEASE EVENT OF MAY 1991..... . . . . . . . . . . . . 24

4.6 GAS RELEASE EVENT OF AUGUST 1991 . . . . . . . . . . . . . . . 27

4.7 AMOUNT OF GAS RELEASED IN AN EVENT . . . . . . . . . . . . . . 28

4.8 BEST ESTIMATE OF GAS COMPOSITION . . . . . . . . . . . . . 28

5.0 SUMMARY OF STUDIES CONOUCTED TO DETERMINE THE MECHANISMS FOR GAS

GENERATION . . . . . . . . . . . . . . . 31

5.1 POSSIBLE MECHANISMS OF TANK BEHAVIOR ........... 31

5.2 THERMOCHEMICAL DEGRADATION ............... 34

5.2.1 Background Information. . . . . . . . . . . . 34

5.2.2 Comparison to Gas Generation in Tank 241-SY-101 . . . 34

5.3 GAS GENERATION DUE TO RADIOLYTIC PROCESSES . . . . . . . . . 36

5.3.1 Background Information . . . . . . . . . . . . . . 36

5.3.2 Comparison to Gas Generation in Tank 241-5Y-101 ... 37

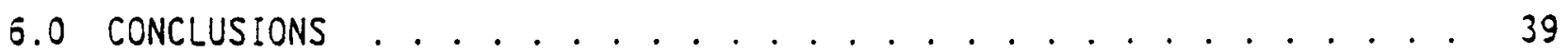

7.0 REFERENCES ..................... . . . 40 
WHC-EP-0517

\section{LIST OF FIGURES}

1 Tank 241-SY-101 Surface Level Readings . . . . . . . . . . . . . . . 4

2 Tank 241-SY-101 Plan View . . . . . . . . . . . . . . . . . . . 6

3 Tank 24l-SY-101 ApriT 19, 1990 Event 12-h Plot.......... . 12

4 Tank 241-SY-101 Apri1 19, 1990 Event--Exhaust Gas Hydrogen Concentration . . . . . . . . . . . . . . . . . . . . . 13

5 Tank 241-SY-101 August 5, 1990 Event--Exhaust Gas Hydrogen Concentration ...................... . 15

6 Tank 241-5Y-101 August 5, 1990 Event--Temperature Profiles.... . 16

7 Tank 241-SY-101--October 24, 1990 . . . . . . . . . . . . . . . . . 17

8 Tank 241-SY-101--October 24, 1990 . . . . . . . . . . . . . . . 18

9 Temperature Versus Time Around Gas Release Event for $300 \mathrm{~s}$. . . . . 19

10 Tank 241-SY-101 October 24, 1990 Event............... 20

11 Tank 241-SY-101 Gas Venting--Hydrogen Concentration Comparisons . . 21

12 Tank 241-SY-101 Gas Venting--Hydrogen Concentration Comparisons . . 22

13 Thermocouple Temperature Comparison Before, During, and After Event . . . . . . . . . . . . . . . . . . . . 23

14 Pressure and Hydrogen Profiles, May 1991 Gas Release Event. . . . . 25

15 Hydrogen Release Profile May 1991 Gas Release Event . . . . . . . . 26

16 Tank 24l-SY-101--Relative Humidity................. 29

17 Postulated Mechanism of Tank 241-5Y-101 Venting . . . . . . . . 33 
WHC-EP-0517

\section{LIST OF TABLES}

1 Tank 241-sY-101 Contents .................. 3

2 Tank 241-SY-101 Total Composition ............. 3

3 Tank 241-SY-101 Gas Monitoring and Analysis ........... 9

4 Tank 241-SY-101 Thermocouple Numbers and Locations......... 10

5 Periodic Release of Gases . . . . . . . . . . . . . . . . 11

6 Comparison of Data from Three Gas Release Events......... 30

7 Gas Volumes for Events................... 31

8 Comparison of Gas Generation in Synthetic Waste Studies with Estimates for Tank 241-5Y-101 ............. 36 
WHC-EP-0517

This page intentionally left blank. 
WHC-EP-0517

\section{EVALUATION OF THE GENERATION AND RELEASE OF FLAMMABLE GASES IN TANK 241-SY-101}

\subsection{INTROOUCTION}

Flammable gas generation in tank 101-SY is a top priority waste tank safety issue at Hanford because average peak concentrations above the lower flammability limit (LFL) for hydrogen occur periodically. Such venting of gases is expected to keep reoccurring until some form of remediation is taken. In addition, it is likely that a greater-than-LFL concentration exists at times within the waste. In the unlikely event an ignition source were present during these periods, a hydrogen burn or explosion could occur with a possible release of nuclear waste to onsite and offsite personnel.

Scenarios of significant concern associated with waste in this tank include the following:

- The potential for ignition of flammable gases such as hydrogen-air and/or hydrogen-nitrous oxide

- The potential for secondary ignition of organic-nitrate mixtures on the crust initiated by the burning of flammable gases or a mechanical in-tank energy source.

Administrative and technical controls are in place to restrict activities that could cause undesirable reactions. Nonsparking tools and use of electrical bonding and grounding techniques are used. So-called "normal" activities for tanks of concern are limited to surveillance. Special safety analysis documents prepared for all work inside the tank are extensively peer reviewed and require U.S. Department of Energy (DOE) approval.

Analyses conducted on several samples of crust material have shown that the crust is quite moist, contains a relatively low total organic carbon and does not exhibit significant exothermic behavior. Thus, "crust burn" does not appear to be an issue. A detailed report on this subject will be issued in fiscal year 1992.

A significant portion of the activities of the Waste Tank Safety Program has been directed at the characterization of the gases that are released from the tank and at the determination of the mechanism for the production of the gases. The purpose of this report is to provide a summary of (1) the methods used for characterization of the gas release events, (2) the data obtained from the recent events, and (3) the results ootained from laboratory studies directed at understanding the mechanisms for the formation of the gases.

Al though 22 other tanks are also suspected of potentially containing smaller accumulations of hydrogen or other flammable gases, this report focuses only on Tank 241-5Y-101. There is a significant difference in significance between Tank 241-SY-101 and the other 22 tanks. Evidence of gas 
WHC-EP-0517

release, surface level behavior, and knowledge of the other tank contents suggests a much lower likelihood of potentialiy dangerous gas concentrations in these other tanks.

\subsection{BACKGROUND INFORMATION ON TANK 241-5Y-101}

Construction on Tank 241-SY-101 was completed in 1976. The first waste put into the tank was from the first double-shell slurry campaign using the 242-S Evaporator in 1977. Double-shell slurry is the most concentrated material that the evaporators can produce. The degree of evaporation is limited only by the pumpability of the slurry. One hundred inches of this material was pumped into Tank 241-SY-101.

From 1977 to 1980 , the tank received complexed concentrate waste, which was placed in the tank at three different times (Table 1 shows the filling history). A total of 203 in. of complexed concentrate waste was placad on top of the heavier double-shell slurry. Complexed concentrate is a waste from the cesium/strontium recovery process in $B$ plant. It is rich in comolexants such as ethylenediaminetetraacetic acid (EDTA), $\mathrm{N}$-(hydroxyethyl)ethylenediaminetriacetic acid (HEDTA), citric and hydroxyacetic acid. These soluble organics were concentrated with the waste stream to a high total organic carbon.

The last material put into Tank 24!-S\%-101 was from another campaign of double-shell slurry in the fall of 1980 . About 84 in. was put into the tank, which brought the final volume to 387 in. Purge water totaling 8,000 gal was added to the tank between September 1984 and May 1988. Table 2 .

The average estimated composition of Tank 241-SY-101 is provided in

The volume of waste in Tank 241-5Y-101 was first noted to increase in 1977 after the first double-shell slurry was put into the tank. This phenomenon was called slurry growth. After the last double-shell slurry campaign, the waste continued to grow and then dropped several inches during a gas release. This cyclic growth and subsequent drop has continued.

Figure 1 shows the cycles of the surface level of the tank during the past several years. Water and air lancing was used for a number of years in an attempt to control the gas releases in the tank. Lancing was stopped in 1989 when the surface level reached 423 in. This was greater than the $422-i n$. operating specification, which is in place to prevent overfilling the tank and overstressing it due to hydrostatic head.

When gas is released into the tank dome spaces, the pressure in the dome space increases. This is an indication that gas is being released. Early laboratory work to identify the cause of the slurry growth phenomena duplicated the gas release phenomenon and indicated that hydrogen is a major component of the slurry growth gas. Since early 1990, there has been an ongoing vapor sampling effort. In addition to hydrogen, subsequent work has identified nitrous oxide, nitrogen, and ammonia among the gases vented. 
Table 1. Tank 241-SY-101 Contents.

\begin{tabular}{|c|c|c|c|}
\hline Tank fill chronology & Gallons & Substance & Inches \\
\hline April 1977 & 274,000 & $\begin{array}{l}\text { Double-shell } \\
\text { slurry }\end{array}$ & 100 \\
\hline November 1977 & 365,000 & $\begin{array}{l}\text { Complexed } \\
\text { concentrate }\end{array}$ & 133 \\
\hline June 1978 & 131,000 & $\begin{array}{l}241-5 x-106 \\
\text { Complexed } \\
\text { concencrate }\end{array}$ & 48 \\
\hline August 1978 & 60,000 & $\begin{array}{l}111-U \text { Complexed } \\
\text { concentrate }\end{array}$ & 22 \\
\hline November 1980 & 230,000 & $\begin{array}{l}\text { Double-she11 } \\
\text { slurry }\end{array}$ & 84 \\
\hline $\begin{array}{l}\text { September } 1984 \text { to } \\
\text { May } 1988\end{array}$ & 8,000 & Water & 3 \\
\hline Total & $1,068,000$ & & 390 \\
\hline
\end{tabular}

Double-shell slurry is a concentrated waste produced by the evaporator. It is high in hydroxide, nitrate, and aluminate concentration.

"Complexed concentrate is an evaporator product similar to double-shell slurry (though not as concentrated). It also contains significant organic complexant concentrations.

Table 2. Tank 241-SY-101 Total Composition.

\begin{tabular}{|l|c|}
\hline \multicolumn{1}{|c|}{ Component } & Concentration \\
\hline $\mathrm{NaOH}$ & $3.22 \mathrm{M}$ \\
\hline $\mathrm{NaAlO}_{2}$ & $1.90 \mathrm{M}$ \\
\hline $\mathrm{NaNO}_{2}$ & $3.28 \mathrm{M}$ \\
\hline $\mathrm{NaNO}_{3}$ & $4.23 \mathrm{M}$ \\
\hline $\mathrm{Na}_{2} \mathrm{CO}_{3}$ & $.62 \mathrm{M}$ \\
\hline $\mathrm{Na}_{2} \mathrm{SO}_{4}$ & $.12 \mathrm{M}$ \\
\hline $\mathrm{Na}_{3} \mathrm{PO}_{4}$ & $.19 \mathrm{M}$ \\
\hline $\mathrm{Pu}_{4}$ & $713(\mathrm{~g})$ \\
\hline $\mathrm{Sr}$ & $2.187 \times 11^{11}(\mu \mathrm{Ci})$ \\
\hline $\mathrm{CS}$ & $3.10 \times 10^{12}(\mu \mathrm{Ci})$ \\
\hline $\mathrm{TOC}$ & $26.24(\mathrm{~g} / \mathrm{L})$ \\
\hline $\mathrm{H}, \mathrm{O}$ & $594,600(\mathrm{gal})$ \\
\hline
\end{tabular}

NOTE: The concentrations are based on

a present average tank height of 408 in. 


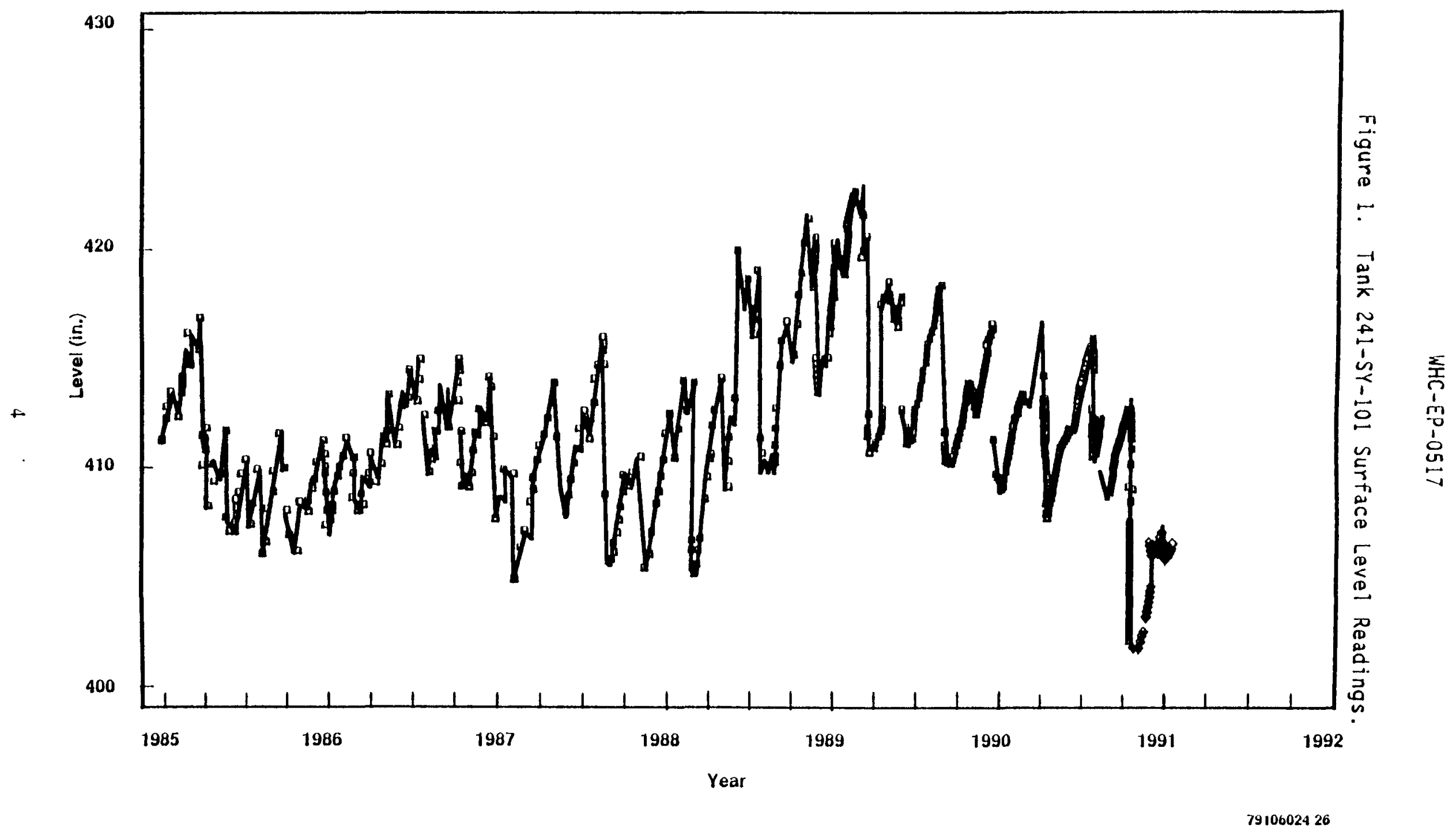


WHC-EP-0517

\subsection{MONITORING OF TANK 241-SY-101}

Semiquantitative identification of the species and amounts of the gases that are released from Tank 241-SY-101 has occurred through the evaluation of data obtained from (1) surface level measurements, (2) tank pressure, (3) flow rate of the ventilation system, and (4) measurement of the gas composition. In addition, significant insight into the venting process has been gained from interpretation of the temperature changes in profiles in the tank during gas buildup and release. The instrumentation used to monitor and characterize the tank is briefly described in the following paragraphs.

\subsection{SURFACE LEVEL MEASUREMENTS}

The original purpose of measuring the surface level in the tank was to monitor for leakage of waste tank contents and to ascertain when the tank was filled to the upper limit. Leakage would be indicated by a drop in suriace leve1. In Tank 241-SY-101, an increase in the surface level indicated a "growth" of the slurry caused by entrapment of generated gases.

Three devices measure surface level in the tank--two conductivity probes and a radar gauge. The automatic conductivity probe is located at riser IC. The manual conductivity probe (manual tape) is locaced at riser 17A. The radar gauge, installed in May 1991, is located at riser 13A. The layout of the risers in the tank is shown in Figure 2 .

Both the automatic conductivity probe and the manual tape work on the same principle, described here in a simplified manner. One electrical contact point is made at the probe, the other at the tank wall. A low energy circuit is closed when the probe contacts the conductive surface of the waste. The level of the surface is determined by the amount of cabie used to lower the probe to the level where the electrical contact is made. The automatic conductivity probe rises to break contact with the waste surface. This rising and lowering of the probe occurs at a preset interval as defined by the Computer Automated Surveillance System analysts. For normal operation, the cycle is repeated every $1.5 \mathrm{~min}$; for enhanced operation (e.g., while ootaining more concentrated information on surface behavior during a vent episode), the cycle is repeated every minute. The Computer Automated Surveillance System has the capability of checking the automatic conductivity probe for its measurement either at the preset interval or upon request. The automatic conductivity probe can also be operated in a manual mode in the field.

The manual tape plummet is lowered into the tank until electrical contact is made with the surface of the waste crust. The reading is recorded on operations $\log$ sheets. Both the automatic conductivity probe and manual tape measurements are required daily. Generally, if the automatic conductivity probe is out of service, the frequency of manual tape readings is increased.

Several nonintrusive (noncontact) methods to determine the surface level have been considered as supplements to or replacements for the automatic conductivity probe and manual tape. A radar gauge was installed on the tank 


\section{Tank 241-SY-101 Plan View}

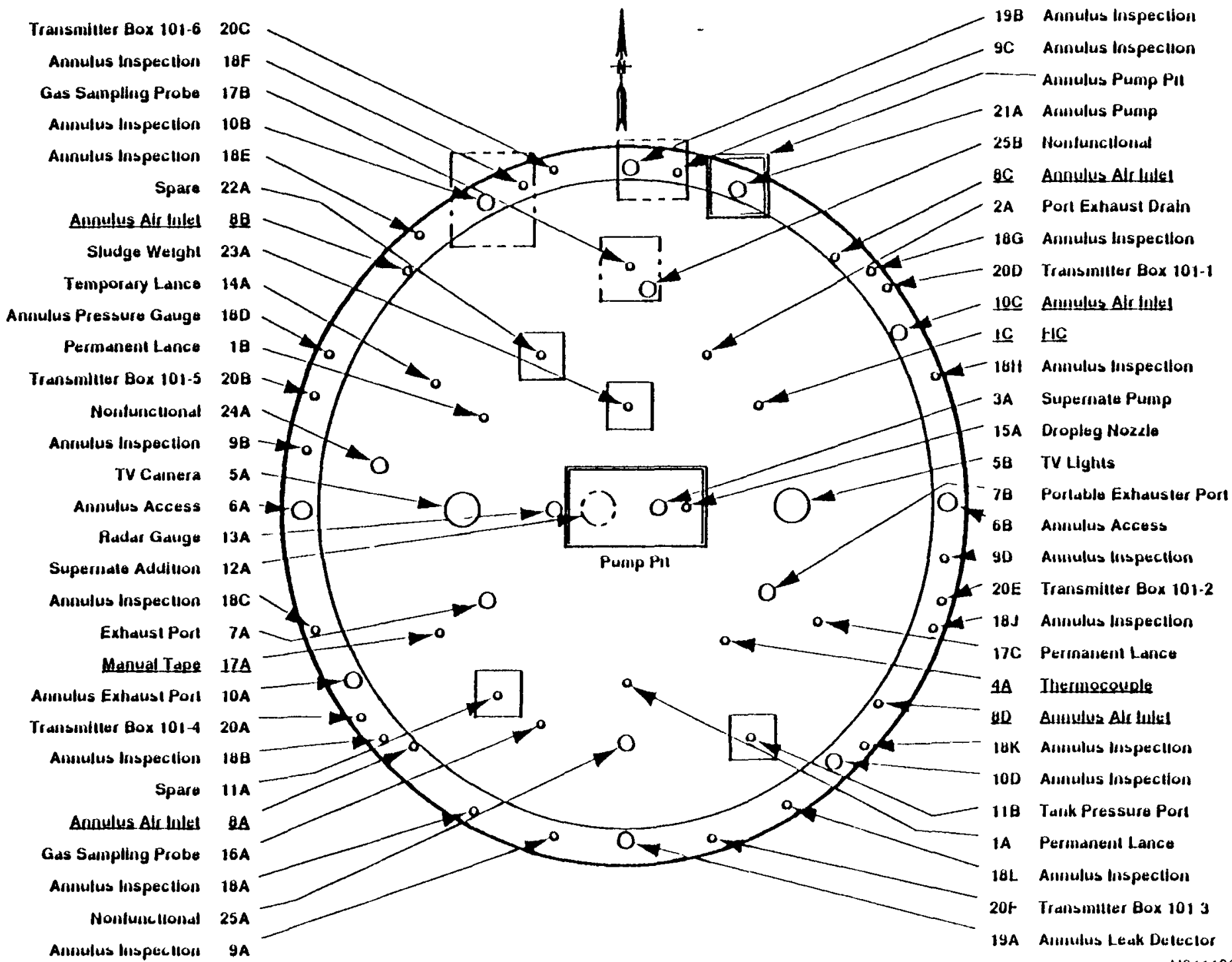


in May 1991. It is intrinsically safe and has a published accuracy of $\pm 2 \mathrm{~mm}$ $( \pm 0.08 \mathrm{in.})$. It averages the level over an area of the crust surface and is not susceptible to errors due to icicle growth or pot-hole formation.

Readings from the radar gauge are shown on a digital LED display located in the 241-SY-271 (271-SY) instrument building. The radar gauge is still in a test mode, and readings are manually recorded on test data sheets by operators. When the testing phase is completed, collection of the radar gauge readings will be automated.

\subsection{TANK PRESSURE}

Two different pressure sensors are used on the tank. Pressure transmitter PT-101-1 monitors pressure at riser 11B (Figure 2). A pressure transducer converts pressure to a 4- to 20-milliamp (mA) current signal, corresponding to $-4-$ to $6-i n$. water gauge $(W G)$. This current signal provides input to a Chessel1' strip chart recorder located in the 271-Sy instrument building. Digital readout is available and is recorded on log sheets, if required. The 4- to 20-mA signal to the chessell recorder is dropped across a 150-ohm resistor in series with a 100-ohm resistor, providing a $0.6-$ to 3-VDC output to the Wavetek ${ }^{2}$ data logger.

The other differential pressure transmitter is located at riser 178 . The output signal is 4 to $20 \mathrm{~mA}$, corresponding to -5 to $\div 20 \mathrm{in}$. WG. The current 1000 signal is dropoed across a 250 -ohm resistor, yielding a 1 - to 5-VDC input to the Hewlett-Packard ${ }^{3}$ data logger.

\subsection{VENTILATION FLOW RATE}

The flow rate in the ventilation header (Figure 2 ) is measured by a flow rate meter. The device transmits a 4- to 20-mA current loop signal to the Chessell strip chart recorder. The signal corresponds to 0 to $1,200 \mathrm{ft}^{3} / \mathrm{min}$ of flow. This signal is dropped across a 150-ohm resistor in series with a 100-ohm resistor to provide an output signal to the Wavetek data logger of 0.6 to 3 VOC.

A second high-range flow transmitter is connected to a strip chart recorder. Its main purpose is to be able to monitor the flow during a gas venting, when the flow rate may approach or exceed $1,200 \mathrm{ft}^{3} / \mathrm{min}$.

\subsection{GAS COMPOSITION}

Gas composition is determined by a number of methods. Some are used on a continual basis and some are used only when an event is thought to be imminent

\footnotetext{
'Chessell is a trademark of Eurotherm International PLC.

Wavetek is a trademark of Wavetek Corporation.

${ }^{3}$ Hewlett-Packard is a trademark of Hewlett-Packard Company.
} 
WHC-EP-0517

with measurements continuing until sometime after the event. The devices and systems used are discussed briefly in the following paragraphs. Table 3 provides a summary of the gas monitoring equipment. Under the heading "Status," On-line indicates the system is on-line at all times; Event Only indicates the system is placed into service to monitor for the event.

The Teledyne hydrogen monitor is located at the ventilation header and monitors for combustible gas in the ventilation system. The monitor determines hydrogen based on thermal conductivity. The monitor provides continuous output to a strip chart recorder and the Wavetek data logger.

Grab samples are taken at intervals determined by a Process Memo prepared prior to each event. They are analyzed in the 300 Area laboratory (mass spectrometer) and provide information about the gas composition. The samples are taken from a port in the ventilation line. The ventilation line port also feeds two gas chromatographs (one for hydrogen only, the second for other gases), the cryogenic sampler, and an ammonia system. These instruments are installed when an event is nearing.

The organic vapor monitor is installed at the SY tank farm stack by the Personal Protective Equipment approximately one week before the anticipated event. It is a nonspecific monitor that indicates ammonia. The readings appear to correlate well with Orager tude sampling, which is used at the stack to indicate ammonia.

A Gas Monitoring System (GMS) was installed as a temporary system in April 1991. The gas is taken from a vapor space sampling tube located below riser 178. The system instrumentation is housed in an instrument shelter on the SY tank farm, near the riser. The GMS is comprised of three main subsystems: (1) a molecular mass spectrometer which analyzes the gas for its components with atomic mass units between 2 and $100,(2)$ a hydrogen monitoring unit, and (3) a differential pressure transmitter.

The sample tubing runs from the riser location to the instrument shelter. A gas sample is drawn into the tubing and analyzed by the molecular mass spectrometer and the hydrogen monitor. The molecular mass spectrometer communicates with a personal computer located in the shelter. Data are then transmitted as an ASCII file over an RS-232 line to the Hewlett Packard (GMS) data logger. The hydrogen monitor provides a 4- to 20-mA current loop signal, which corresponds to $0 \%$ to $50 \%$. The data are transmitted to the Hewlett Packard data logger.

Two other risers have three sampling tubes each installed for future use by an on-line GMS. These are not now in use but could be connected to provide a total of 10 gas monitoring locations in the tank (the ventilation header and 3 risers with three different levels in the dome space each). The plans for an additional on-line GMS are currently under development.

"Teledyne is a trademark of Teledyne, Inc.

SDrager is a trademark of Oragerwerk AG Lubeck. 
Table 3. Tank 241-SY-101 Gas Monitoring and Analysis.

\begin{tabular}{|c|c|c|c|c|}
\hline instrument & bocation & $\begin{array}{c}\text { Cycle time (event eycle time } \\
\text { shown in brackers) }\end{array}$ & $\begin{array}{l}\text { Gas components } \\
\text { analyzed }\end{array}$ & Sratus \\
\hline $\begin{array}{l}\text { Gas monitoring system } \\
\text { mass spectrometer }\end{array}$ & $\begin{array}{l}\text { Riser } 178, \\
\text { near crust } \\
\text { probe }\end{array}$ & $5 \min$ & 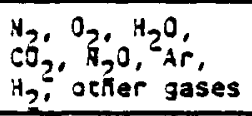 & On-line \\
\hline $\begin{array}{l}\text { Gas monitoring system } \\
\text { hydrogen monitor }\end{array}$ & $\begin{array}{l}\text { Riser } 178, \\
\text { near crust } \\
\text { probe }\end{array}$ & $\begin{array}{l}5 \text { min, normal race } 10 \mathrm{~s} \text {, iast } \\
\text { race ifast race scarts on } \\
\text { increased pressure and/or } \\
\text { hydrogen] }\end{array}$ & $\mathrm{H}_{2}$ & on-line \\
\hline $\begin{array}{l}\text { Teledyne hydrogen } \\
\text { monitor }\end{array}$ & Vene header & $\begin{array}{l}10 \mathrm{~s}, 1 \text { min, or } 10 \text { min (set to } \\
10 \mathrm{~s} \text { in anticipacion of the } \\
\text { event] }\end{array}$ & $\mathrm{H}_{2}$ & On-line \\
\hline $\begin{array}{l}\text { Grab samoles (orf-line } \\
\text { gas analysis) }\end{array}$ & Vent heacer & $\begin{array}{l}\text { [Sample every } 10 \text { min unt il } \\
\text { hydrogen level is less than } \\
\text { i\%; then samole every half } \\
\text { hour for minimum } 2 \text { h; then } \\
\text { samole every hour uncil } \\
\text { cermination requested? }\end{array}$ & 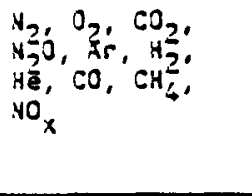 & Event onity \\
\hline Ammonia system & Vene header' & $\begin{array}{l}\text { (8) }(4 \text { sess of } 2 \mathrm{~h} \text { each); } \\
\text { auro start on }-1 \text { in. 'dG.1 }\end{array}$ & $\mathrm{NH}_{3}$ & Event only \\
\hline Gryogenic sampler & Vent neader & [6 $\mathrm{n}$; aueo start on -1 in. $\mathrm{dal}$ & Organics, $\mathrm{NH}_{3}$ & Event only \\
\hline Gas chromarographs (2) & Vent header ${ }^{1}$ & $\begin{array}{l}\text { ¿4 min eycle :ime. Juring and } \\
\text { after event: concinuous une } i l \\
\text { hydrogen level is less inan } \\
1 \% \text { then samole every nalf } \\
\text { hour for ninimum of } 2 \mathrm{~h} \text {; then } \\
\text { samole every hour uncil } \\
\text { termination requestedl }\end{array}$ & 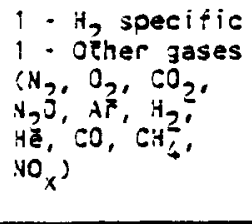 & Event onity \\
\hline Organic vapor monitor & $\begin{array}{l}\text { stacx, :ank } \\
\text { farm }\end{array}$ & $\begin{array}{l}\text { Ginstall aoproximacely } 1 \text { weex } \\
\text { before event; cycle sime set } \\
\text { to } 1 \text { minl }\end{array}$ & $\mathrm{NH}_{3}$, organies & Event only \\
\hline
\end{tabular}

The vent header gas sample port location is upstream of the psychometric port.

\subsection{TEMPERATURE MEASUREMENTS}

The temperature of the waste is obtained from a single thermocouple (TC) tree located at riser 4A. Eighteen Type J TCS are bonded pipe that is located in a 4-in. riser. Thermocouple 1 is the lowest TC in the tank, with higher numbered TCs higher in the tank. Thermocouple 17 is near the surface of the waste, and TC 18 is in the tank dome space above the waste. Table 4 provides the height of the TCs in the tank. Photographs taken in the tank show that the TC tree is slightly bent, so the heights given are not necessarily precise.

From the TC tree in the tank, TC wire is run through two junction boxes to an 18-position selector switch (SS-101-1) located in the 271-SY instrument bullding. The TCs are read manually using a hand-held digital TC reading device. These readings are recorded on log sheets daily, once a shift, or hourly, as directed by process Memo. They have traditionally provided a record of the daily temperatures at the various heights in the tank. A parallel connection has been made from the TC wires to a Wavetak data logger, also located in the 271-Sy instrument building. Prior to a gas release event, the recording interval is set to $10 \mathrm{~s}$. 
Table 4. Tank 241-SY-101 Thermocouple Numbers and Locations.

\begin{tabular}{|c|c|c|}
\hline $\begin{array}{c}\text { Thermocouple } \\
\text { number }\end{array}$ & $\begin{array}{c}\text { Instrument } \\
\text { number }\end{array}$ & $\begin{array}{c}\text { Nominal he ight } \\
\text { from tanx } \\
\text { bottom (in.) }\end{array}$ \\
\hline$T / C 1$ & $T E-101-37$ & 4 \\
\hline$T / C 2$ & $T E-101-38$ & 28 \\
\hline$T / C 3$ & $T E-101-39$ & 52 \\
\hline$T / C 4$ & $T E-101-40$ & 76 \\
\hline$T / C 5$ & $T E-101-4 !$ & 100 \\
\hline$T / C 5$ & $T E-101-42$ & 124 \\
\hline$T / C 7$ & $T E-101-43$ & 148 \\
\hline$T / C 3$ & $T E-101-44$ & 172 \\
\hline$T / C 9$ & $T E-101-45$ & 196 \\
\hline$T / C 10$ & $T E-101-46$ & 220 \\
\hline$T / C 11$ & $T E-101-47$ & 244 \\
\hline$T / C 12$ & $T E-101-48$ & 258 \\
\hline$T / C 13$ & $T E-101-49$ & 292 \\
\hline$T / C 14$ & $T E-101-50$ & 316 \\
\hline$T / C 15$ & $T E-101-51$ & 340 \\
\hline$T / C 16$ & $T E-101-52$ & 364 \\
\hline$T / C 17$ & $T E-101-53$ & 412 \\
\hline$T / C 18$ & $T E-101-54$ & 460 \\
\hline
\end{tabular}

In addition to the TCS in the tank space, a TC and temperature transmitter are located in the ventilation header space. The ventilation temperature data and relative humidity are logged to a Hewlett-Packard data logger located in the GMS shelter.

\subsection{SUMMARY OF GAS RELEASE EVENTS}

In the spring of 1990, an increased emphasis was placed on the characterization of the gas releases from Tank 241-SY-101. In the past 2 years, these episodic releases have occurred about every 100 days. Table 5 provides a summary of the events of 1990 and 1991 . 
Table 5. Periodic Release of Gases.

\begin{tabular}{|l|c|c|c|c|}
\hline \multicolumn{1}{|c|}{ Event date } & $\begin{array}{c}\text { Number of } \\
\text { days since } \\
\text { last event }\end{array}$ & $\begin{array}{c}\text { Change in } \\
\text { surface } \\
\text { level, in. }\end{array}$ & $\begin{array}{c}\text { Peak } \\
\text { pressure, } \\
\text { in. (WG) }\end{array}$ & $\begin{array}{c}\text { Peak } \mathrm{H}_{2} \\
\text { conc., \% }\end{array}$ \\
\hline January 1990 & 109 & $-7 . \mathrm{i}$ & - & - \\
\hline Apri1 19,1990 & 110 & -8.3 & +0.1 & 3.5 \\
\hline August 5, 1990 & 109 & -5.2 & -1.96 & 1.2 \\
\hline October 24,1990 & 80 & -10.3 & +2.3 & 4.7 \\
\hline February 13,1991 & 110 & -5.3 & -2.0 & 0.04 \\
\hline May 16, 1991 & 82 & -7.2 & +0.25 & 0.5 \\
\hline August 1991 & -- & $\leq 5$ & -2.83 & 0.56 \\
\hline
\end{tabular}

It is not the intent of this report to srovide a detailed description of each event; rather, selected observations will be presented. Detailed reports are issued for each gas release event.

\subsection{GAS RELEASE EVENT OF APRIL 1990}

On Apri1 19, 1990, Tank 241-SY-101 siar:ad to release gas, and the majority of the release occurred in a 6 - to $3-n$ period. This event released sufficient gas to briefiy pressurize the tank dome space to to.l in. WG and caused the hydrogen concentration to peak at about 3.5 vol\% in the exhaust header. This is shown in Figure 3. The to ial surface level drop was 8.3 in., but the lowest level did not occur until 11 days after the event. Several instruments were employed to evaluate the concentration of hydrogen during the event. From those listed in Table 3, the April 1990 event utilized the Teledyne monitor, a gas chromatograph, and a grab sample, which were sent to a laboratory mass spectrometer. Figure 4 snows that good agreement was obtained between the three systems. Data from tne mass spectrometar evaluations showed that nitrous oxide was also released during ine event. An estimation technique for the gas composition showed that it was 30 to 33 mol\% hydrogen and 20 to 25 mol\% $N_{2} 0$ (Allemann 1991). A detailed evaluation of the April 19, 1990 event is given in Burke et al. (1991).

\subsection{GAS RELEASE EVENT OF AUGUST 1990}

Unlike the April 1990 event, the August 1990 event was very mild. Both the surface level and pressure response indicated a much slower release of gas. The total surface drop was 5.2 in., and the peak hydrogen concentration in the exhaust header was about 1.2\%. As with the April 1990 event, the various instruments provided good agreement on the hydrogen release, which is 


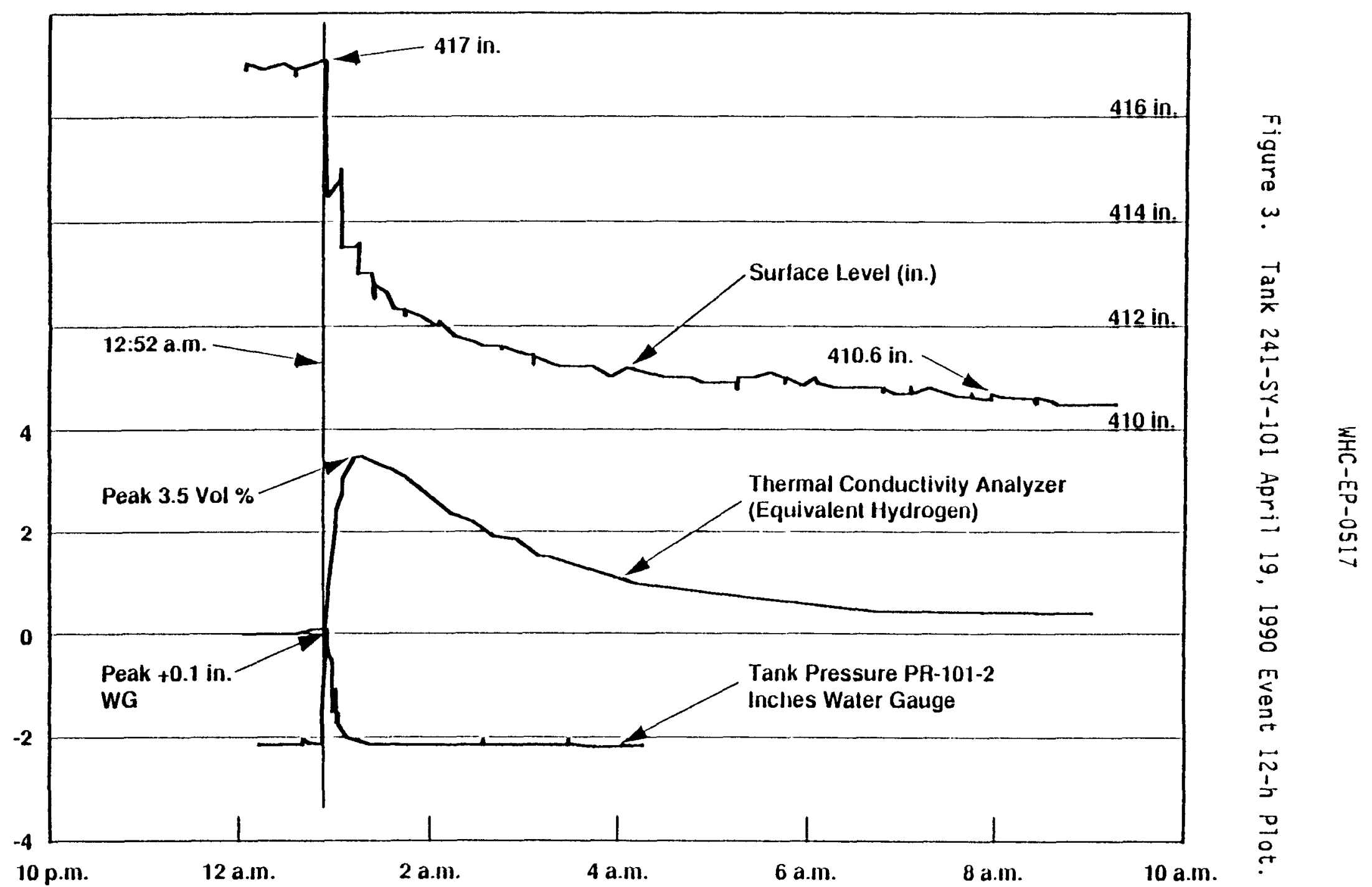

April 19,1990 


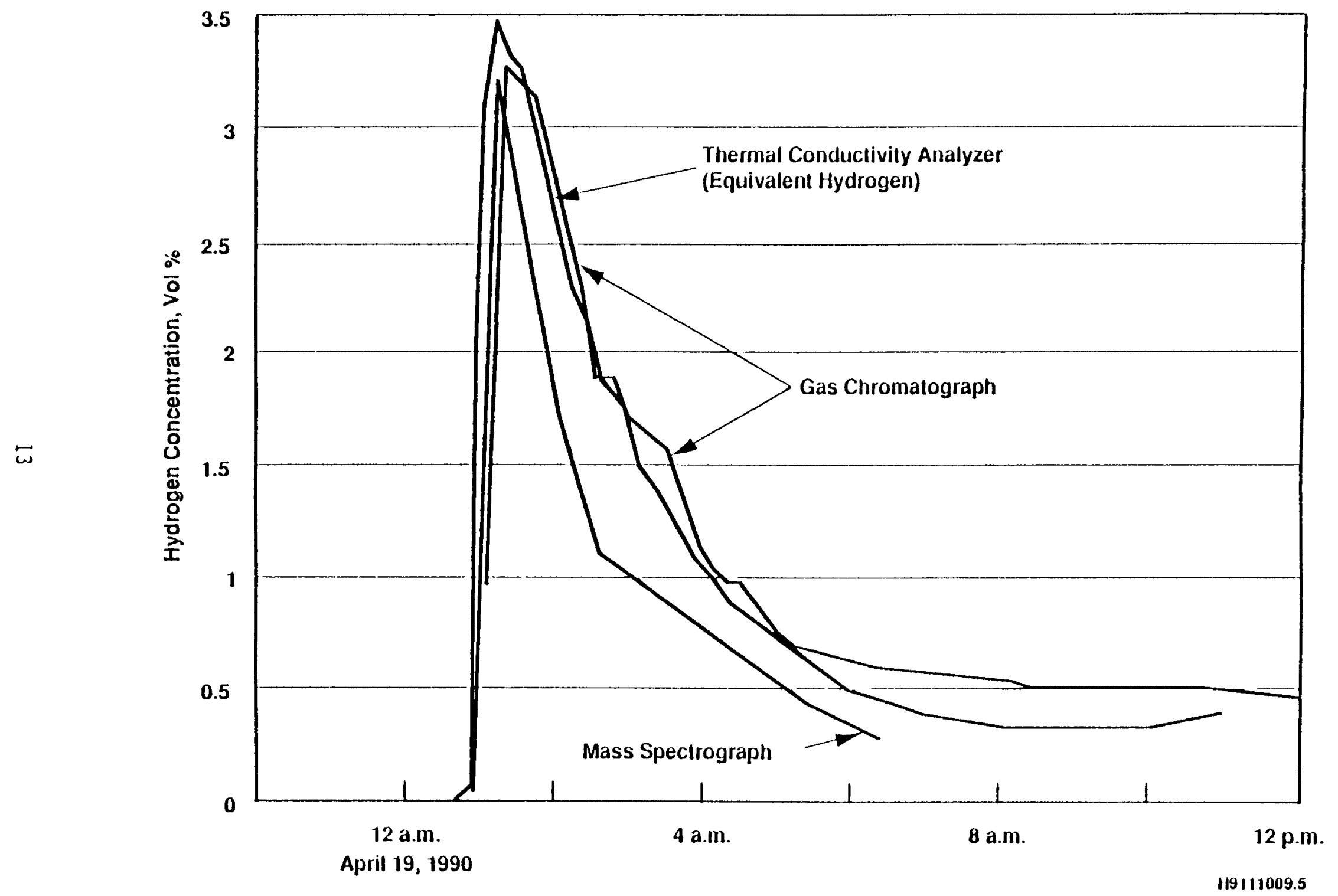

年

宁

$\overrightarrow{0} \%$

April 19, 1990 
shown in Figure 5. Grab samples of the gas were sent to the Idaho National Engineering Laboratory for analys is with their precision mass spectrometer. The mean composition from these analyses was 40 mol\% hydrogen $( \pm 1.4)$, 32.9 mol\% nitrous oxide $( \pm 1.2)$, and $28 \mathrm{~mol} \%$ nitrogen $( \pm 2.1)$.

Figure o shows the temperature profiles of the tank both before and after the event. Before the event, the temperature profile exhibited a pronounced bulge in the lower portion, a nearly isothermal region in the upper portion, and a steep gradient at the too surface. During a gas release event, it has been postulated that the waste in the lower region moves to the upper region because of excess buoyancy. The temperature profile shows a decrease in temperature in the "bulge" in the lower part and an increase in temperature just below the waste surface. After the gas has been released, the temperature profile gradually reverts to the pre-event condition. A detailed evaluation of this event is given by Carothers et al. (1989).

\subsection{GAS RELEASE EVENT OF OCTOBER 1990}

One of the improvements added to the instrumentation systems before the October 1990 event was the capability to record the temperature at 10-s intervals. Just before a high-pressure alarm signaled a release in the morning of October 24, 1990, the temperature profile underwent a rapid reversal. Temperature records showed that the upward movement of the hotter material started about 10 s before the colder material moved downward. The entire tank appeared to "roll over" in less than $90 \mathrm{~s}$. This is illustrated in Figures 7,8 , and 9 . Figures 7 and 8 show the entire profile, while figure 9 shows data for only two thermocouples, one at the bottom $(\neq 4)$ and one at the top $(+16)$.

The October 24, 1990 event has been the "largest" event ever recorded for Tank 241-SY-101 in that the event produced the largest amount of hydrogen, the largest increase in pressure, and one of the largest drops in surface level. Figure 10 provides a summary of the pertinent data. Again, good agreement on the amount of hydrogen released was found for the three measurement methods shown in Figure 11. A comparison of the hydrogen release for the Aprit, August, and October 1990 releases is given in Figure 12 .

Barker (1991) provides the detailed analysis of the October 1990 event.

\subsection{GAS RELEASE EVENT OF FEBRUARY 1991}

This event was rather mild, in that there was little increase in either the tank pressure or hydrogen concentration. A total drop of 5 in. was recorded over a period of $g$ days. No data were obtained on gas composition. The temperature profile change for this event is provided in Figure 13 . Note that only a partial "rollover" occurred; this was quite similar to the August 1990 event (Figure 6 ). A report for this event is being prepared and is scheduled for release in November 1991. 


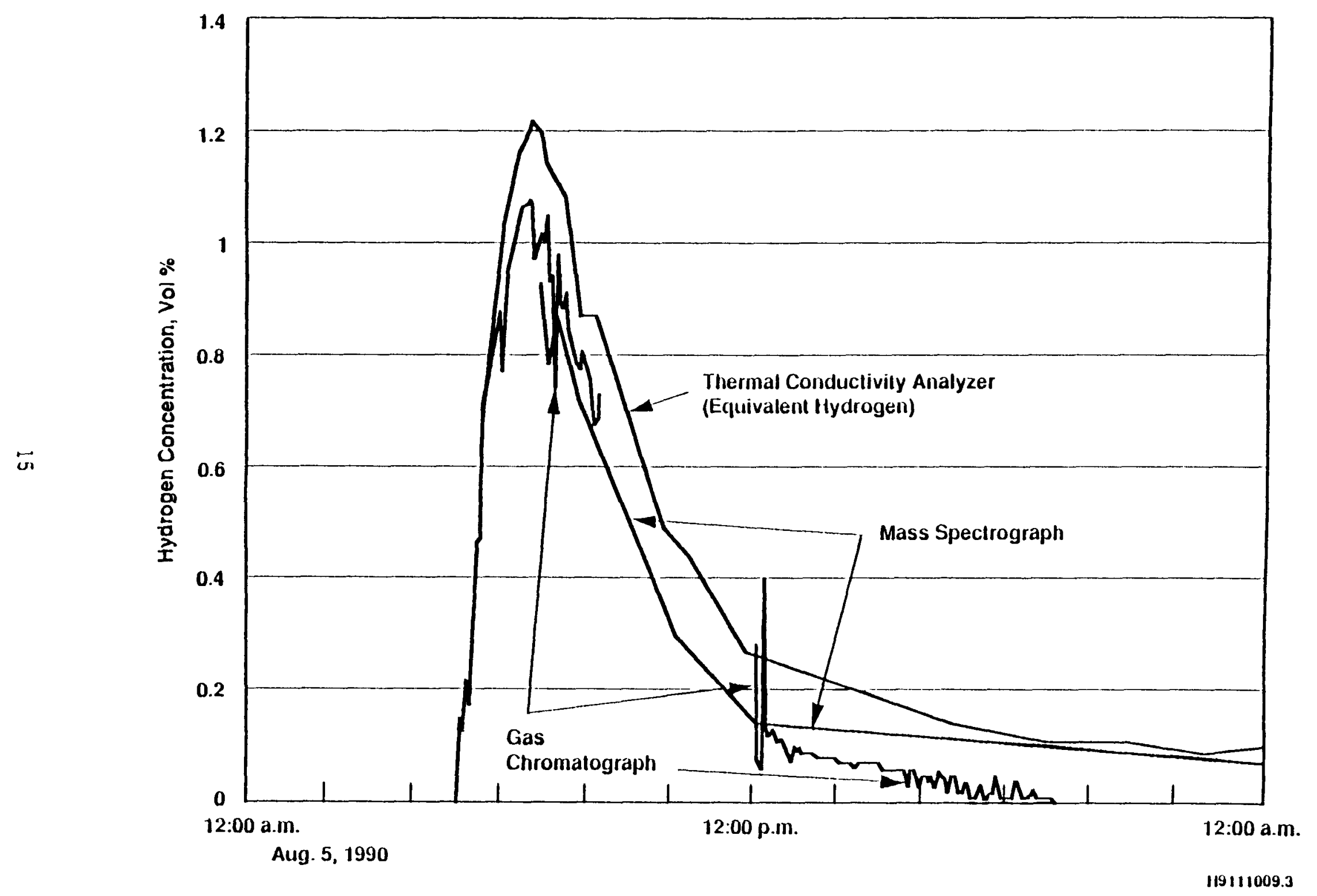

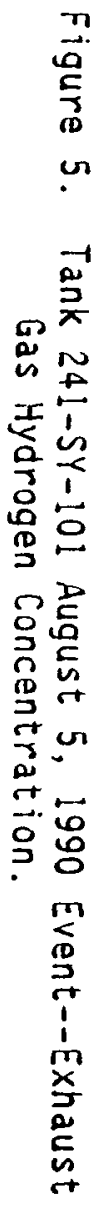




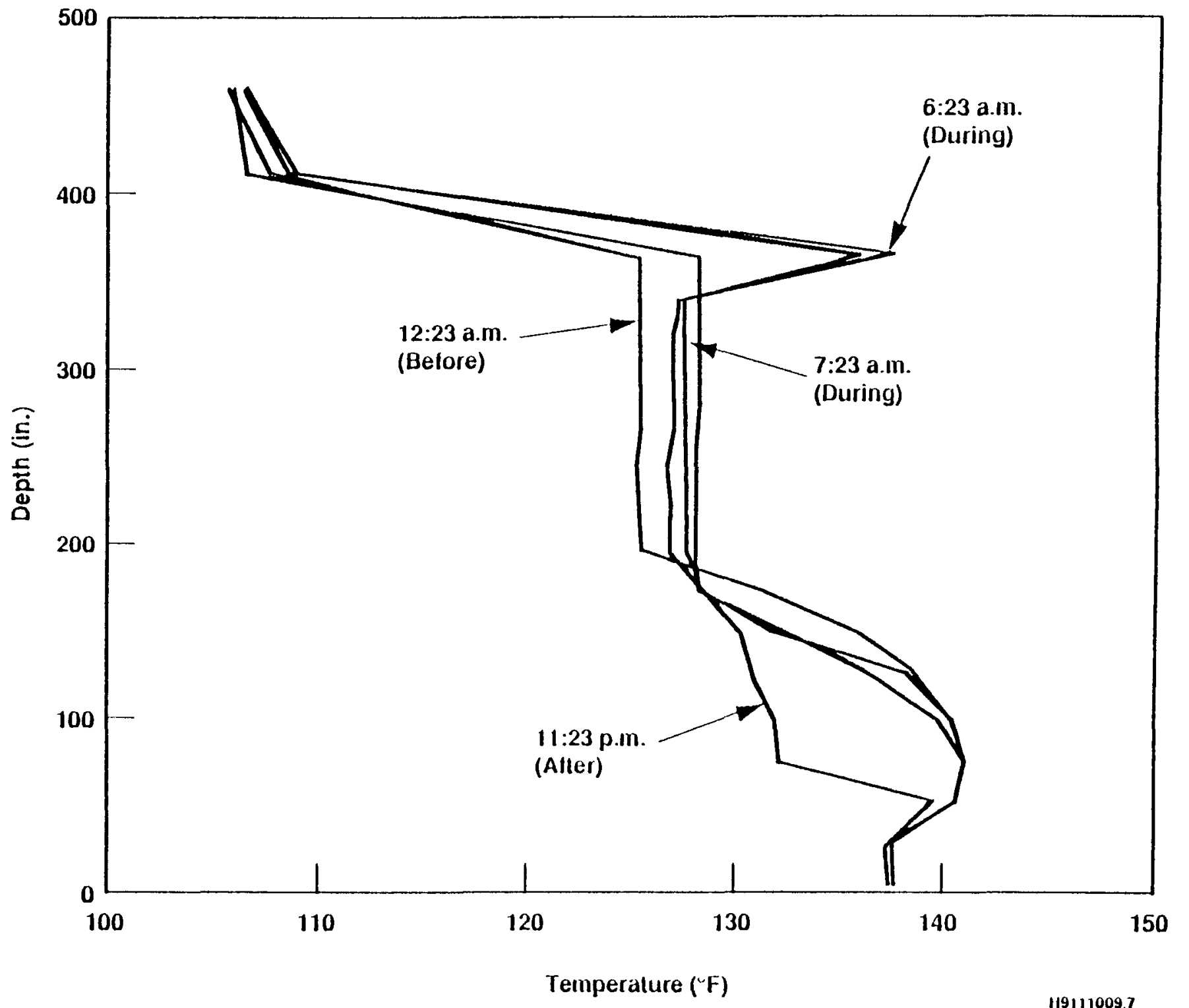

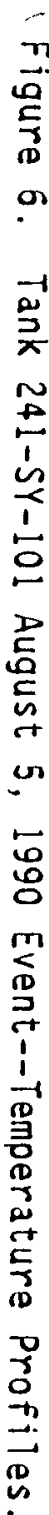


Figure 7. Tank 241-SY-101--October 24, 1990.

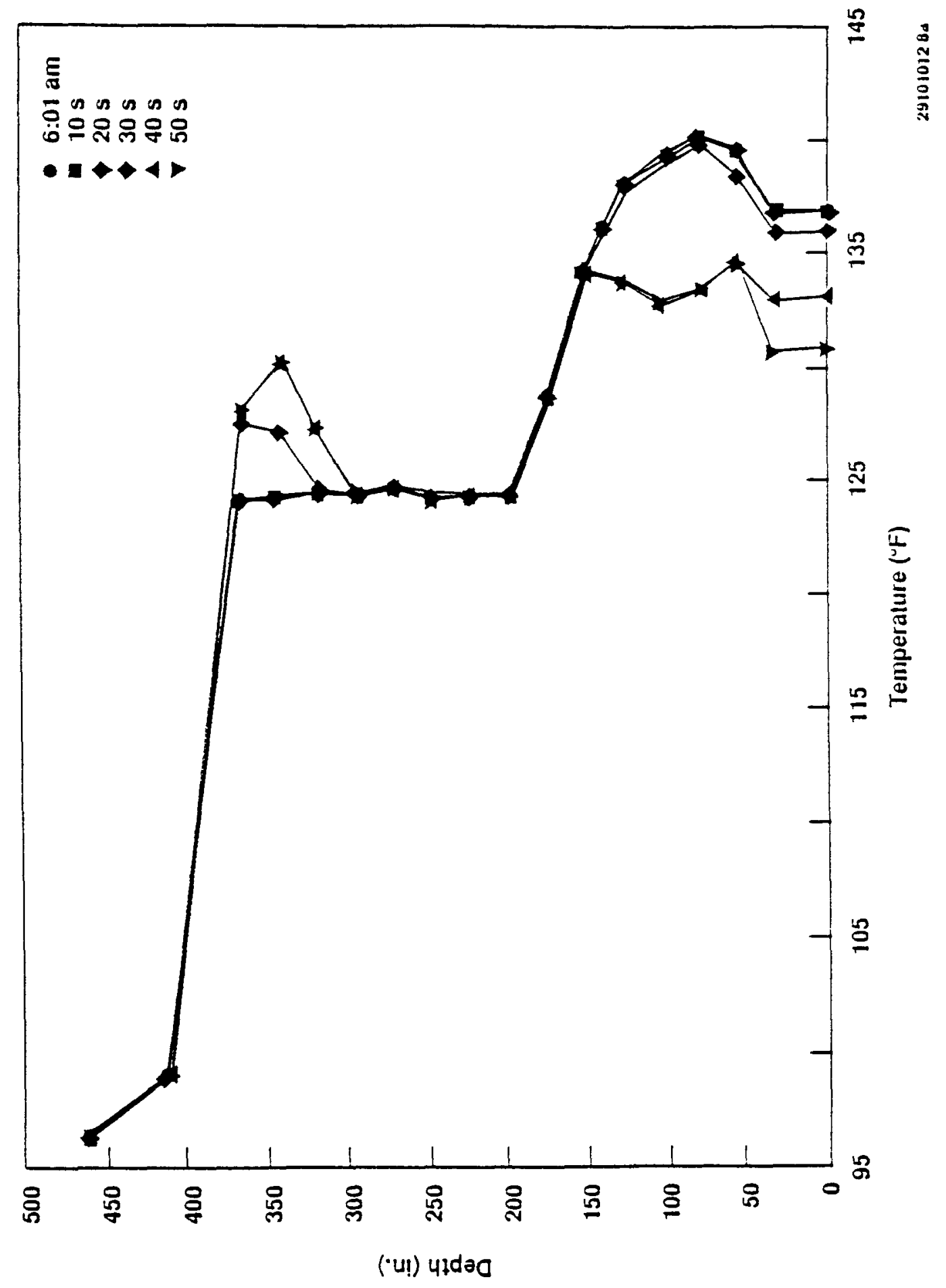


WHC-EP-0517

Figure 8. Tank 241-5Y-101--October 24, 1990.

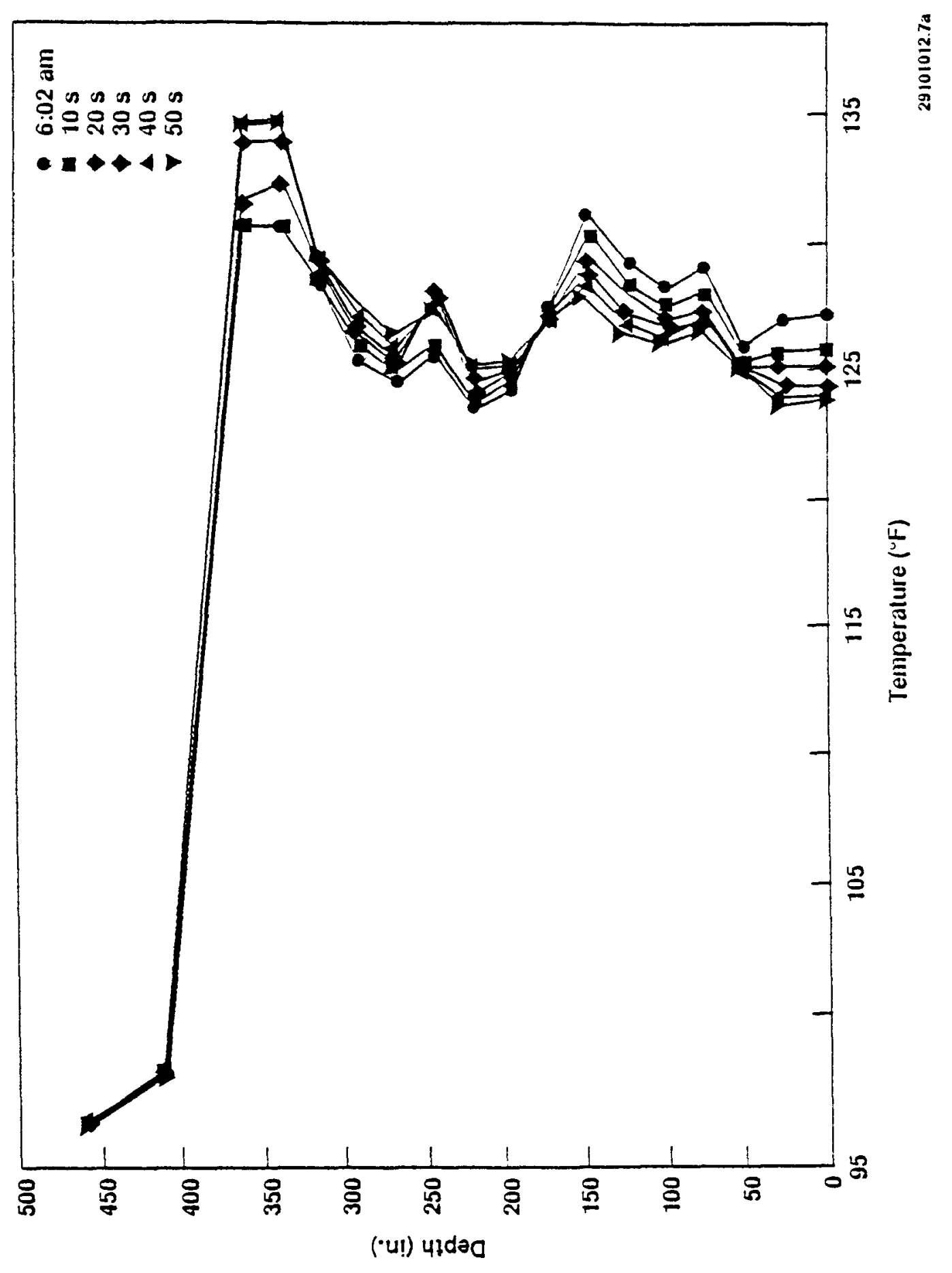




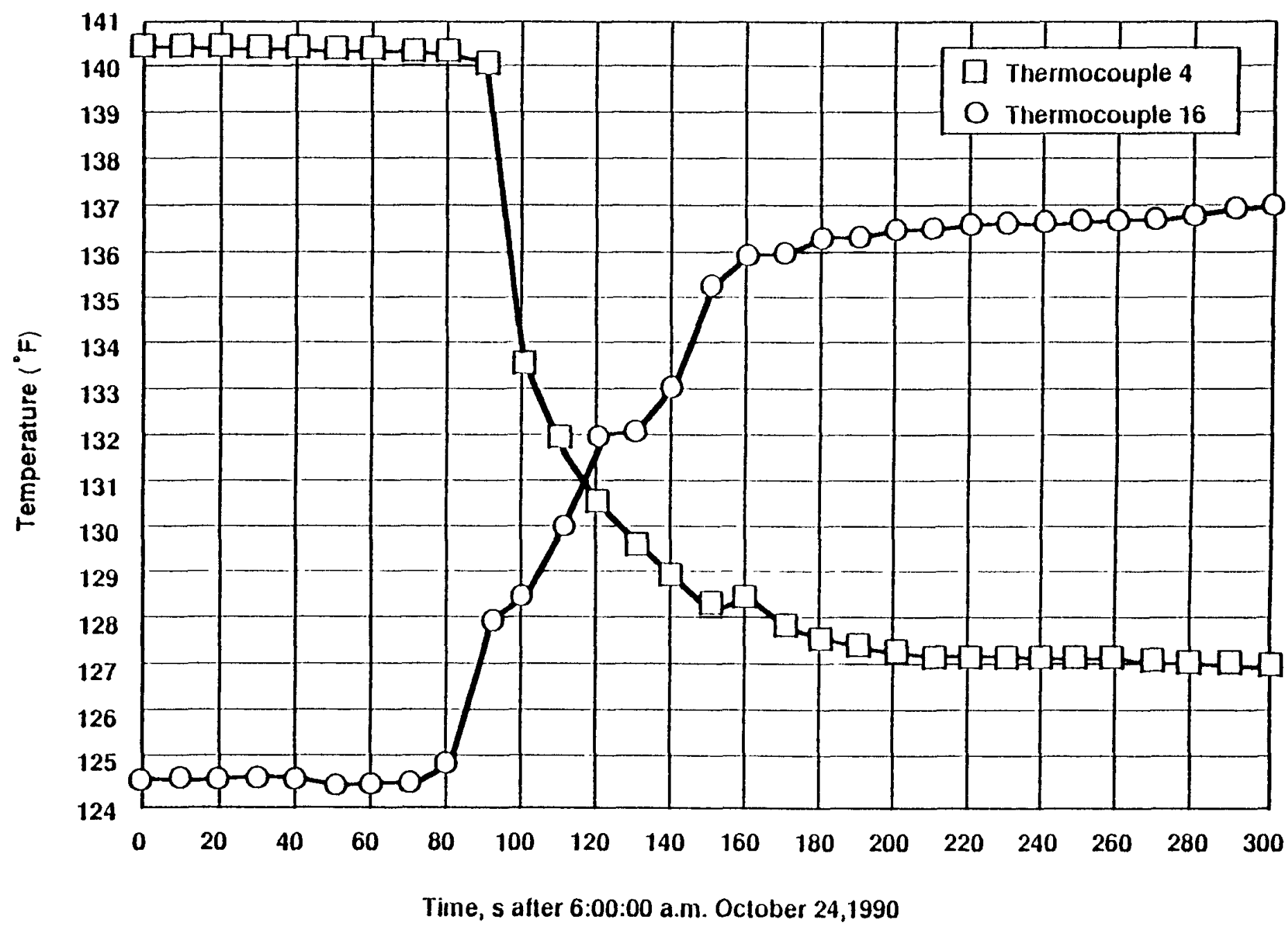

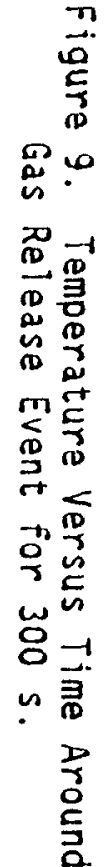




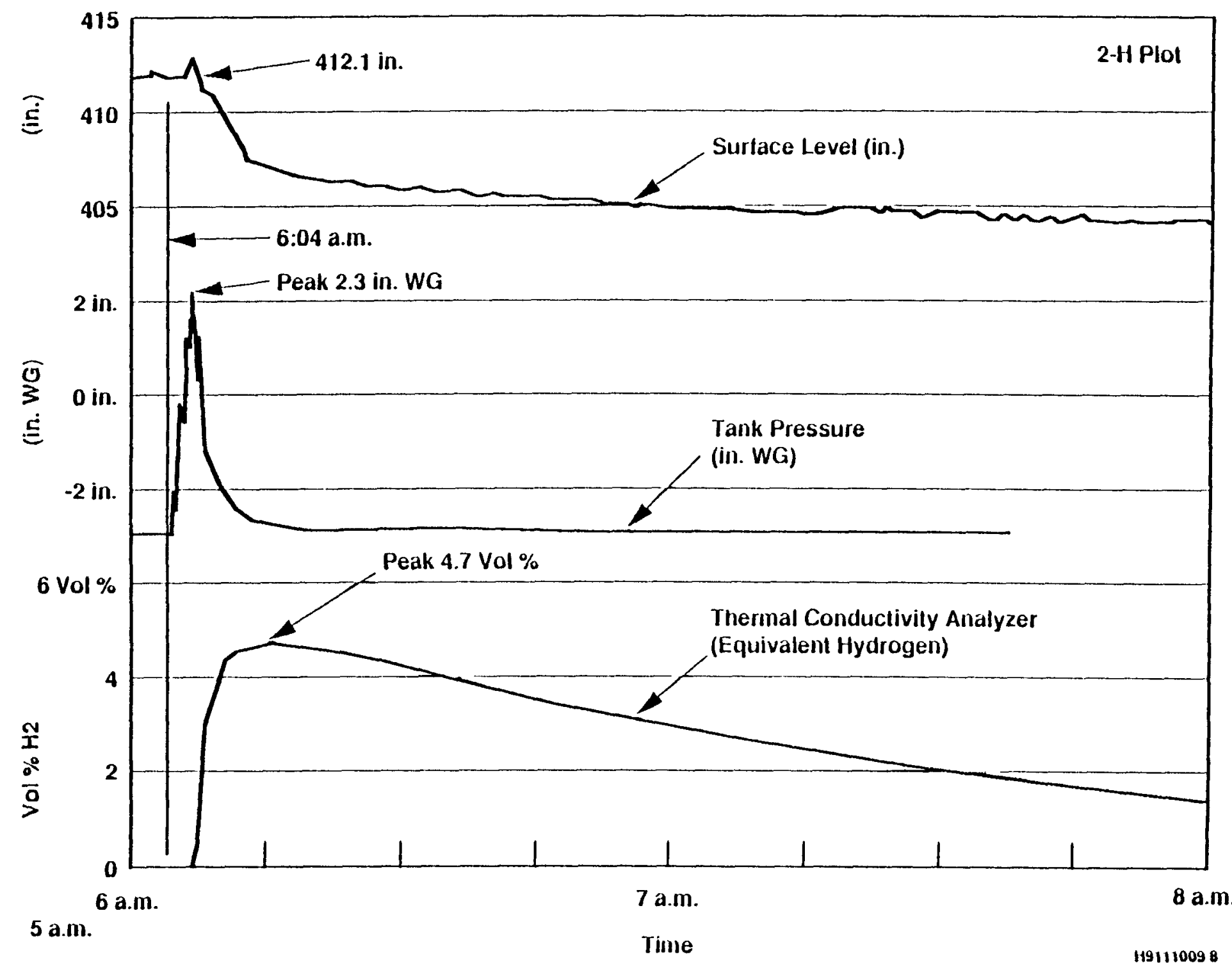

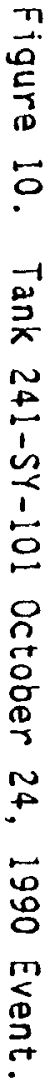




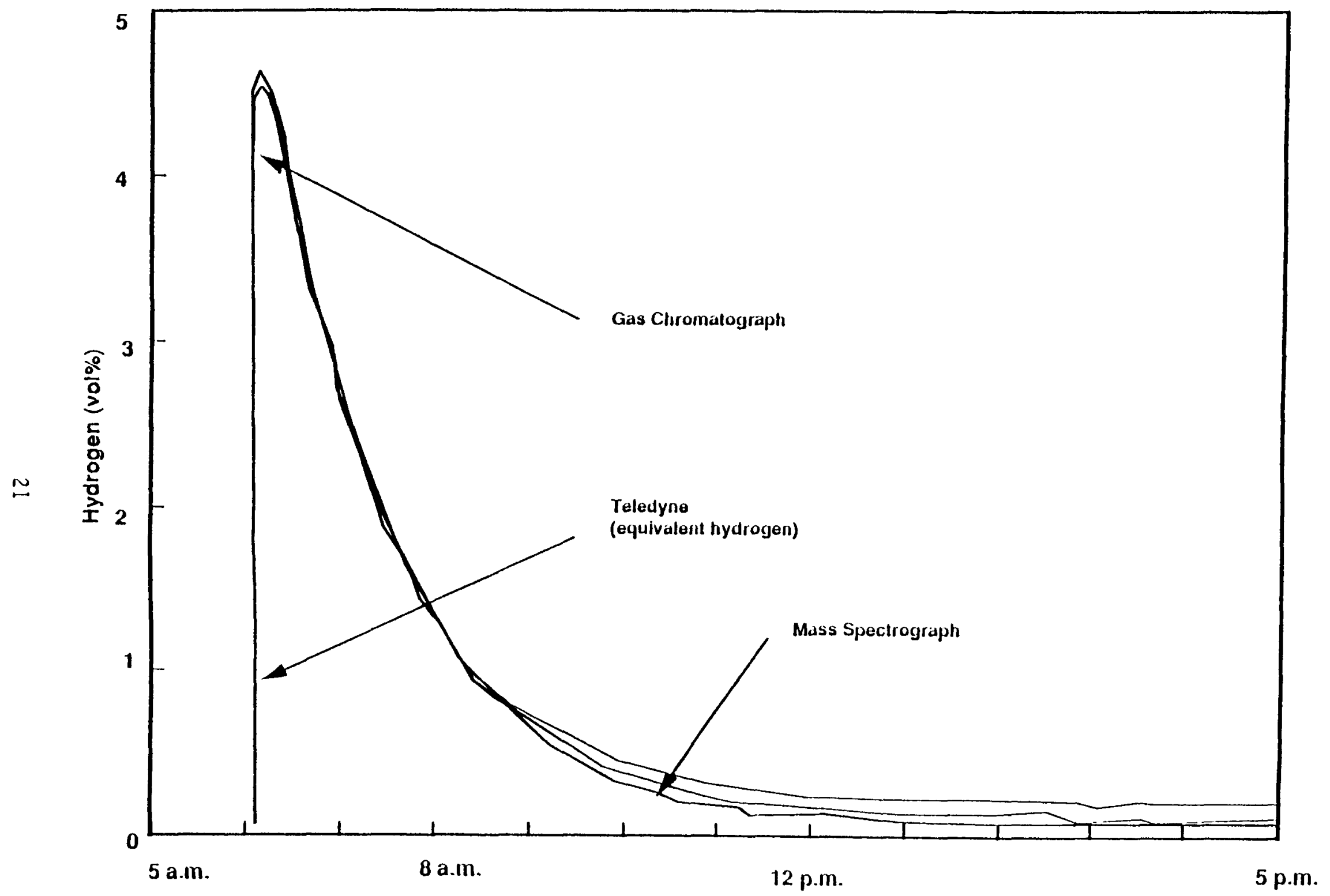

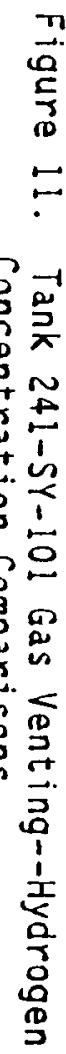

Figure 3-4 


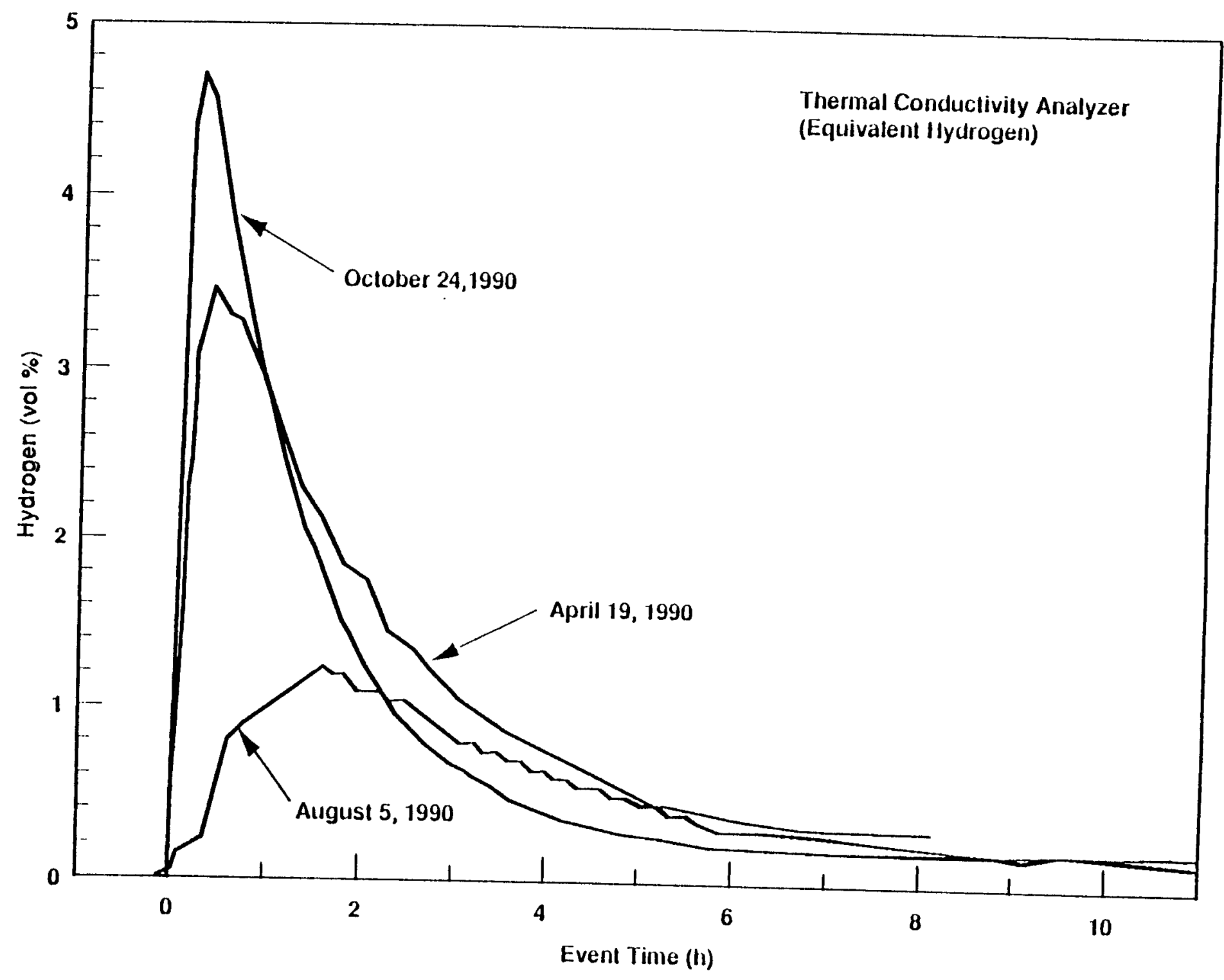

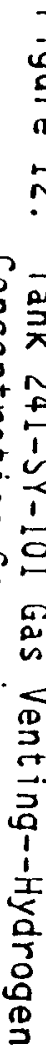




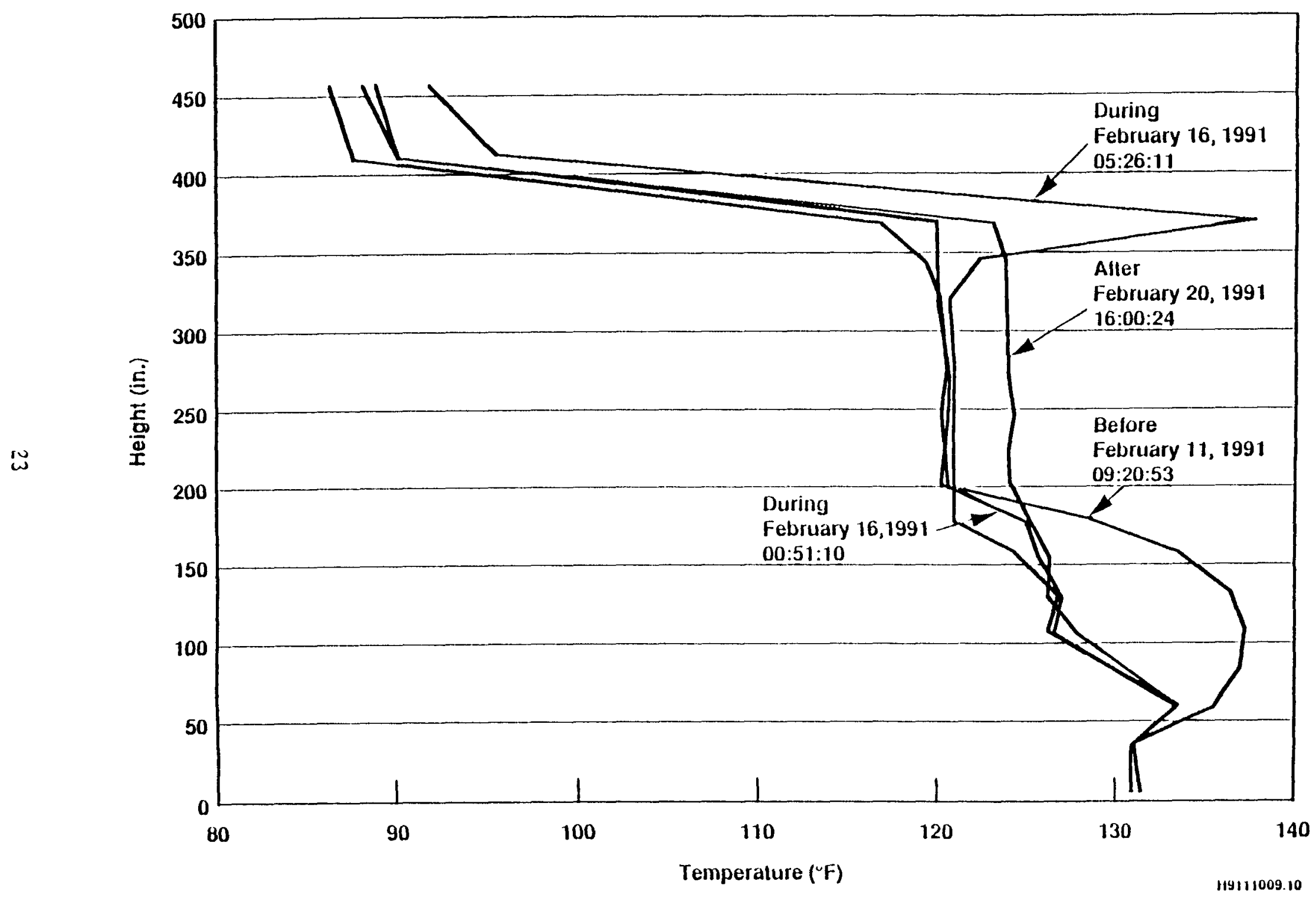




\subsection{GAS RELEASE EVENT OF MAY 1991}

Before this event, the on-line mass spectrometer and a hydrogen-specific monitor were set up to sample a probe that had been inserted into the tank dome space at riser 178 .

The tank pressure and hydrogen behavior in the exhaust header for this event are shown in Figure 14. This event did produce a slight positive pressure of $0.25 \mathrm{in}$. WG in the dome space, but it was at a positive value for less than $20 \mathrm{~s}$.

Figure 15 provides a comparison of the hydrogen measurements from the tank dome space and in the exhaust header. Note that the whittaker unit was used for the dome space and the Teledyne unit sampler for exhaust header. For each location there is good agreement between the hydrogen-specific monitor and the results from a mass spectrometer.

While these methods do agree well with the concentration of hydrogen in the vapor space, the hydrogen monitors cannot estimate the gas composition. The gas composition is estimated by the mass spectrometer samples. Two different mass spectrometer instruments are being used. Grab samples were taken and sent to Pacific Northwest Laboratory for high-resolution mass spectrometer analysis. The on-line mass spectrometer measures gases at near real time from the sample port about $18 \mathrm{in}$. above the waste.

Based on the on-line mass spectrometer analyses, the composition of vented gas was estimated. To do this, only the gas samples that had over $1 \%$ hydrogen were considered to ensure that the vent gas would be in larger quantities and the analysis would be more accurate. Because of the greater dilution in the ventilation system, none of the grab samples indicated greater than $1 \%$ hydrogen. Therefore, these samples are too dilute to yield meaningful gas compositions, and the on-line mass spectrometer was used for the May 1991 event gas composition estimates.

The gas analyzed by the on-line mass spectrometer is a combination of ventilation air mixed with the gas released by the waste. The released gas tends to be a small portion of the total. To estimate this gas, the argon is used as a tie element so that an amount of air proportional to the argon is subtracted from the measured gas to get the estimated gas composition released from the waste.

The amount of argon in the samples varied, which influenced the final results. For example, the air measurements taken by the on-line mass spectrometer had an average argon concentration of $0.92 \%$. There is about a $10 \%$ variation in the argon value. When the argon is used to adjust larger values such as nitrogen, a small variation makes a large difference in the answer.

When air was subtracted out of the measured composition using argon as a tie element, the oxygen varied around zero. There were aporoximately the same number of negative values as positive values. This indicated that oxygen

\footnotetext{
Whittaker is a trademark of Whittaker Electronic Resources.
} 


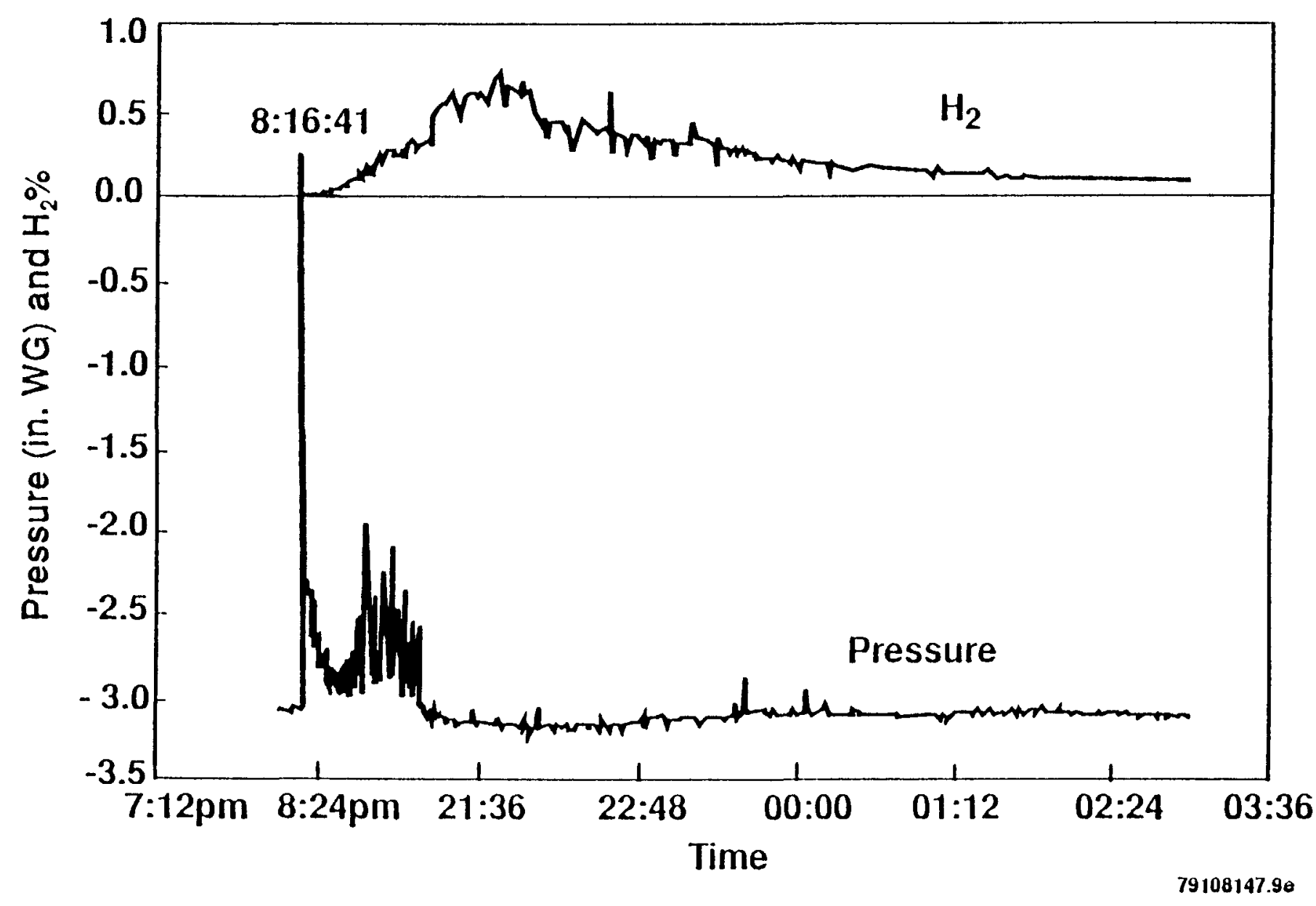




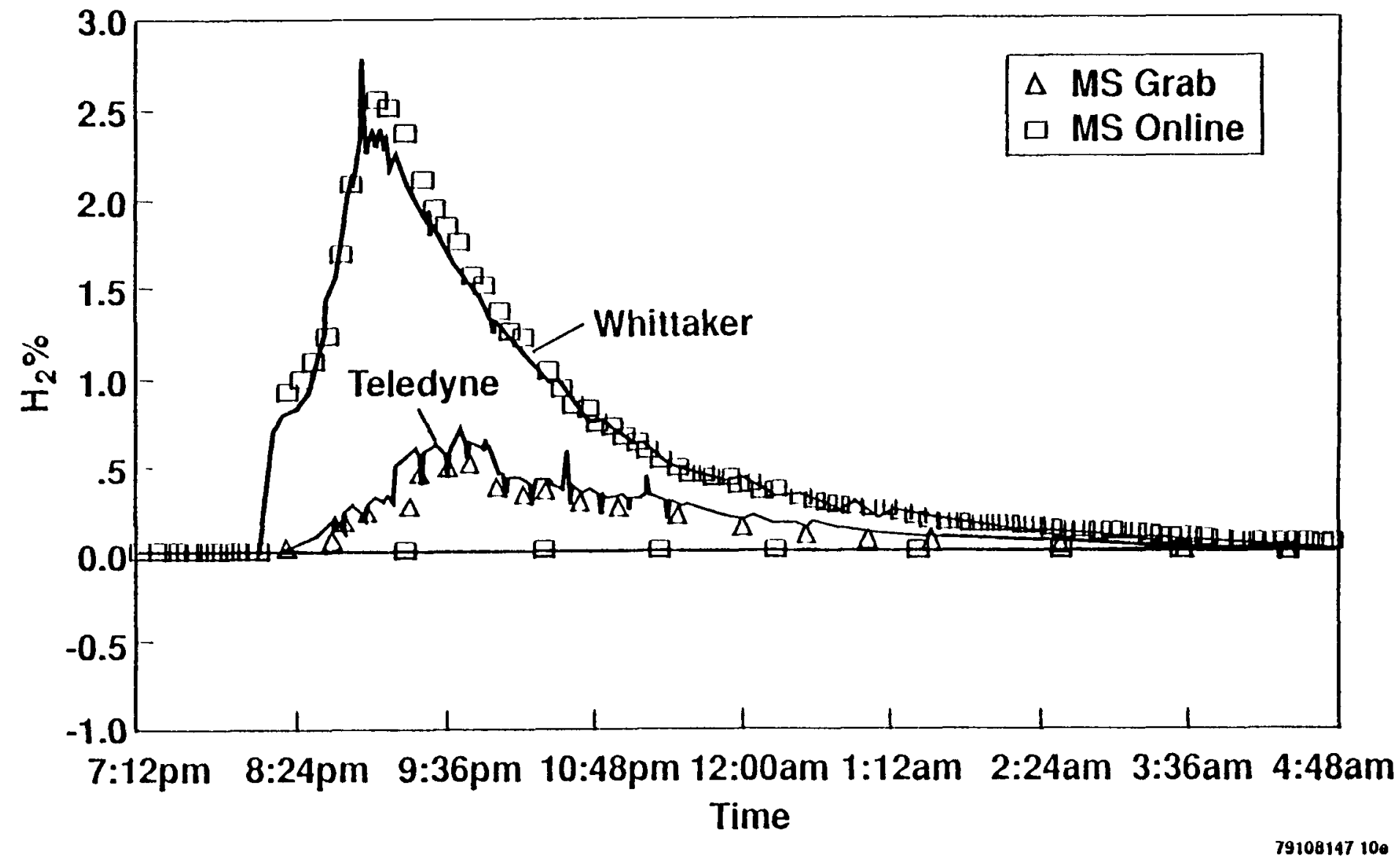

79108147100 
probably is not part of the vent gas. The oxygen values were set to zero, and the resulting gas composition was normalized to $100 \%$. The results are tabulated below.

\begin{tabular}{lc} 
Estimated gas comoosition \\
\hline $\mathrm{H}_{2}$ & $15.4 \%$ \\
$\mathrm{H}_{2} \mathrm{O}$ & $17.7 \%$ \\
$\mathrm{~N}_{2}$ & $57.7 \%$ \\
$\mathrm{~N}_{2} \mathrm{O}$ & $9.1 \%$ \\
$\mathrm{CO}_{2}$ & $.1 \%$ \\
\hline
\end{tabular}

It should be pointed out that the water may not be measured accurately with the on-line mass spectrometer. The mass spectrometer is not kept at the same temperature as the tank head space so the water may condense. Also, the moisture may represent some water that was evaoorated into the ventilation air when the air came in contact with the wasta. Water certainly does play a large part in the composition of the gas.

One of the differences between the grab sample mass spectrometer analysis and the on-line mass spectrometer analysis was the nitrous oxide-to-hydrogen ratio. The $\mathrm{N}_{2} \mathrm{O} / \mathrm{H}_{2}$ ratio for the grab sample has measured near 0.75 for several gas ventings. The on-line mass spectrometer indicates that this ratio would be closer to 0.0 . Perhaps the problem is that part of the response to nitrous oxide is recorded in mass 45 instead of mass 44 . This would make the reported response of nitrous oxide lower than actual value.

The gas composition determined by the on-line system is different than that from the gas sampler (Sections 4.2 and 4.3 ). The values reported here for the on-line mass spectrometer are still being reviewed and evaluated. There is ongoing work both at Westinghouse Hanford Company and Pacific Northwest Laboratory to try to improve the understanding of the released gases, and a full discussion will be provided in the evaluation report for the event.

\subsection{GAS RELEASE EVENT OF AUGUST 1991}

During the period of August 26 to 29, 1991, Tank 241-5y-101 exhibited some of the characteristics associated with a gas release event. This event appeared to be similar to the events in August 1990 and February 1991. There was a very small increase in tank pressure and hydrogen concentration. The temperature profile did not exhibit a full reversal.

The on-line mass spectrometer peaked at $0.28 \%$ hydrogen and the whittaker unit recorded $0.38 \% \mathrm{H}_{2}$. An increase of $0.13 \% \mathrm{H}_{2}$ was noted by the Teledyne monitor on the exhaust header. 
Video recordings on August 26 and 27 showed areas that "rolled over" together with numerous bubbles. Even though the television camera showed considerable surface movement of the waste, the TC data did not show the complete removal of the "temperature bulge" in the lower portion of the tank.

An additional piece of information from the mass spectrometer and the humidity monitor in the exhaust header showed significant increases in relative humidity on both August 26 and 27 (see Figure 17).

\subsection{AMOUNT OF GAS RELEASED IN AN EVENT}

Using the estimates of gas composition, the flow rate for the ventilation and the hydrogen release profiles (e.g., Figure 12), it is possible to estimate the total amount of gas released in the various events. The most recent set of analyses was given in Barker (1991). A summary of the calculations is given in Table $\sigma$.

The released gas volume can also be calculated from the change in the surface level of the tank. Assuming that the entire surface of the tank waste moves in a uniform manner during an event and that the gas behaves as an ideal gas, the volume of gas was calculated for two cases: (1) the specific gravity of the waste equals 2 , and (2) the specific gravity equals 1.6 . Table 7 presents the results. These values are in general agreement with those in Table 6 .

\subsection{BEST ESTIMATE OF GAS COMPOSITION}

In Section 4.2, the composition of the gas, based solely on mass spectrometer data, was $40 \% \mathrm{H}_{2}, 32 \% \mathrm{~N}_{2} \mathrm{O}$, and $28 \% \mathrm{~N}_{2}$. Barker (1991) reported that the October 1990 data yielded a composition of $38 \% \mathrm{H}_{2}, 32 \% \mathrm{~N}_{2} \mathrm{O}$, and $30 \% \mathrm{~N}_{2}$. These two rosuits are in good agreement, considering the difficulties in estimating the constituents in a diluzed gas stream. These analyses do not account for the condensable gases $\left(\mathrm{H}_{3} \mathrm{O}\right.$ and $\left.\mathrm{NH}_{3}\right)$. Barker (1991) showed that ammonia was detected during the October 1990 event, and most recentiy it was also detected in the May 1991 event. Figure 17 shows that water vapor also is present. In consideration of the fact that the trapped gases at the bottom of the waste are under about two atmospheres of pressure and that the total pressure is composed of the vapor pressure of the various gases, a calculation was made to determine the amount of minor constituents in the released gases. At this point in time, the best estimate for the gas composition is as follows:

$\begin{array}{ll}\text { Hydrogen } & 36 \% \\ \text { Nitrogen } & 37 \% \\ \text { Nitrous oxide } & 28.5 \% \\ \text { Water } & 4 \% \\ \text { Ammonia } & 4 \% \\ \mathrm{SCO}_{2}, \mathrm{CH}_{4} \mathrm{CO} & 0.5 \%\end{array}$

Continued monitoring of the tank will heip to improve the knowledge of the specific gases released in the events. 


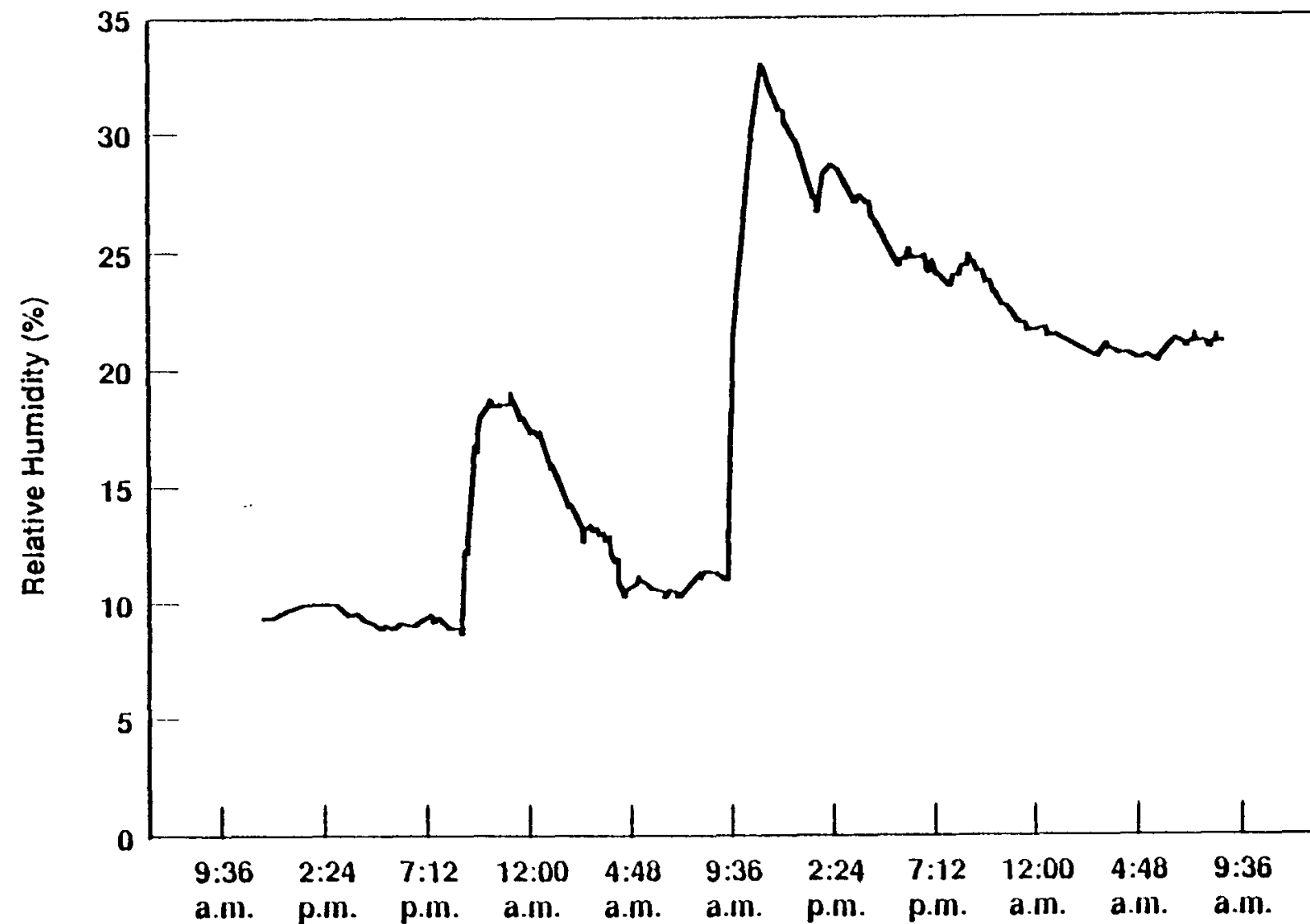

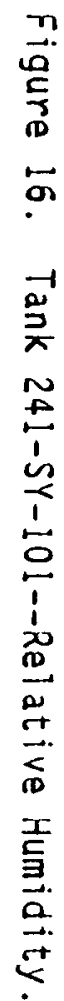

August 26-28, 1991

119111009.11 
Table 6. Comparison of Data from Three Gas Release Events.

\begin{tabular}{|c|c|c|c|c|c|c|}
\hline Date & $\begin{array}{c}\text { Crust level } \\
\text { change } \\
\text { (in.) }\end{array}$ & $\begin{array}{c}\text { Pressure } \\
\text { peak } \\
\text { (in. WG) }\end{array}$ & $\begin{array}{l}\mathrm{H}_{2} \text { concentration } \\
\text { peak }(\mathrm{mol} \%)\end{array}$ & $\begin{array}{l}\mathrm{H}_{2} \text { gas } \\
\text { releasse } \\
\left(\mathrm{ft}^{3}\right)\end{array}$ & $\begin{array}{c}\text { Total gas } \\
\text { releasse } \\
\left(\mathrm{ft}^{3}\right)\end{array}$ & $\begin{array}{l}\text { Steady-state } \\
\text { ventilation } \\
\text { flow rate } \\
\left(\mathrm{ft}^{3} / \text { inin) }\right.\end{array}$ \\
\hline $4 / 19 / 90$ & -9.3 & 10.1 & 3.5 & 3,600 & $\begin{array}{l}11,000 \\
\pm 2,700\end{array}$ & 371 \\
\hline $8 / 05 / 90$ & -5.2 & -1.96 & 1.2 & 1,900 & $\begin{array}{r}7,000^{b} \\
\pm 3,600\end{array}$ & 417 \\
\hline $10 / 24 / 90$ & -10.2 & 12.3 & 4.7 & 3,200 & 8,400 & 600 \\
\hline
\end{tabular}

${ }^{a}$ Calculated values.

Assumes 27 mol\% hydrogen in evolved slurry growth gas. At 40 mol\% hydrogen, total gas amounts to 4,800 $1450 \mathrm{ft}^{3}$. 
Table 7. Gas Volumes for Events.

\begin{tabular}{|l|c|c|c|}
\hline \multicolumn{1}{|c|}{ Date } & Drop $\left(\mathrm{ft}^{3}\right)$ & Minimum $\left(\mathrm{ft}^{3}\right)$ & Maximum $\left(\mathrm{ft}^{3}\right)$ \\
\hline Apri1 1990 & 9.3 & 6,140 & 8,930 \\
\hline August 1990 & 5.2 & 3,430 & 4,990 \\
\hline October 1990 & 10 & 6,600 & 9,600 \\
\hline February 1991 & 5 & 3,300 & 4,800 \\
\hline May 1991 & 7.2 & 4,300 & 7,200 \\
\hline August 1991 & 5 & 3,000 & 5,000 \\
\hline
\end{tabular}

\subsection{SUMMARY OF STUDIES CONDUCTED TO DETERMINE THE MECHANISMS FOR GAS GENERATION}

\subsection{POSSIBLE MECHANISMS OF TANK BEHAVIOR}

A number of hypotheses have been proposed to explain the mechanisms of gas generation, but more information from characterization, modeling, and laboratory simulation studies is needed jefore we can fully understand and olan to mitigate the tank hazards. work is in progress at westinghouse Hanford Company, Argonne National Laboracory, the Georgia Institute of Technology, and Pacific Northwest Laboratory to determine the exact mechanism of gas generation and release. Since the cause of the cycle is not yet known, cycilic hydrogen generation and release is an unreviewed safety question.

Based on analysis of the off-gas stream, a mixture of hydrogen, nitrous oxide, and nitrogen gas appears to form as the product of radiolysis and/or the chemical decomposition of the organic chemicals in Tank 241-SY-101. Insight into tank chemistry and the processes associated with gas generation requires that information be obtained by :aking a full core sample of the contents of the tank. According to our current hypothesis, tank gases appear to be formed continuously in the whole tank, but appear to be formed and stored preferentially in the nonconvective sludge layer in the bottom portion of the tank. This storage phenomenon creates a supersaturated "solution" of gas in the tank. Unknown instabilities trigger a movement of the waste towards the top of the tank thereby releasing the stored gas.

The temperature profile change (Figure $5-7$ ) gives insight to the mechanism that causes the periodic releases. There seems to be a chemical reaction, assisted by radiation effects that generate the gas. The gas-trapping mechanism appears to be due to hydraulic and physical methods.

Before a gas release, the bottom part of the tank shows a profile that has a maximum temperature near the middle of this region. This is a classic shape temperature profile for material with a volumetric heat source and in which the heat is dissipated by conduction. The indications are that this layer contains settled solids that do not move. The radioactive decay heats 
this layer uniformly, but the heat can flow from both the bottom and top of the layer. Hence, those areas are cooler than the center of the layer.

Above this layer is a layer that has a very uniform temperature. This is an indication of a fluid convective heat transfer zone. Heat generated in this zone and transferred to it from below is the driving force to move the fluid by convection. The convection mixes the layer and keeps the temperature uniform.

After a gas release, the temperature profile is commonly uniform. This shows that the entire tank has been stirred up, indicating a "rollover" in the tank. Indeed, when the iemperatures are studied more closely, it is common to see the hot material from the bottom rise to the top and lodge there for some time.

While other mechanisms have been proposed, this rollover has stood up under scrutiny and explains the observations. Figure 16 shows a schematic of what is believed to be happening.

The chemical reaction (involving the organics and assisted by the radiation) is producing gas throughout the tank. In the convective layer, the motion of the fluid brings the gas generaced in that layer up to the surface where it can be released. This does not allow the gas to accumulate in the fluid layer. However, in the lower layer, the waste does not move. Most of the gas formed in this layer is retained.

This layer becomes less dense due to the accumulated gas. The temperature rises, which does several things. The warmer temperature causes the accumulated gas to expand, further decreasing the density. The increased temperature decreases the viscosity of the naterial. Some of the solid material redissolves in the warmer temperacure. The chemical reaction rate may aiso increase.

Finally, the lower level reaches a critical density and becomes buoyant. This causes instability, and the lower region rolls over to the top. When this happens, the hydrostatic head decreases, the pressure on the accumulated gas drops, and the buboles expand. This further increases the buoyancy. The gas releases when it gets to the surface.

Eventually, enough of the accumulated gas is released so that the solids can settle out. The nonconductive layer forms once more on the bottom and the cycle starts over again.

The current thought is that the crust is not a barrier to gas. The crust is estimated to be several feet thick. During a burp, the force of the event is strong enough to physically disrupt the crust and allow the gas to escape. The top portion of the crust layer probably dries out between the events. It has been postulated that the crust is a foamy mixture of liquid, solids, and gas. 


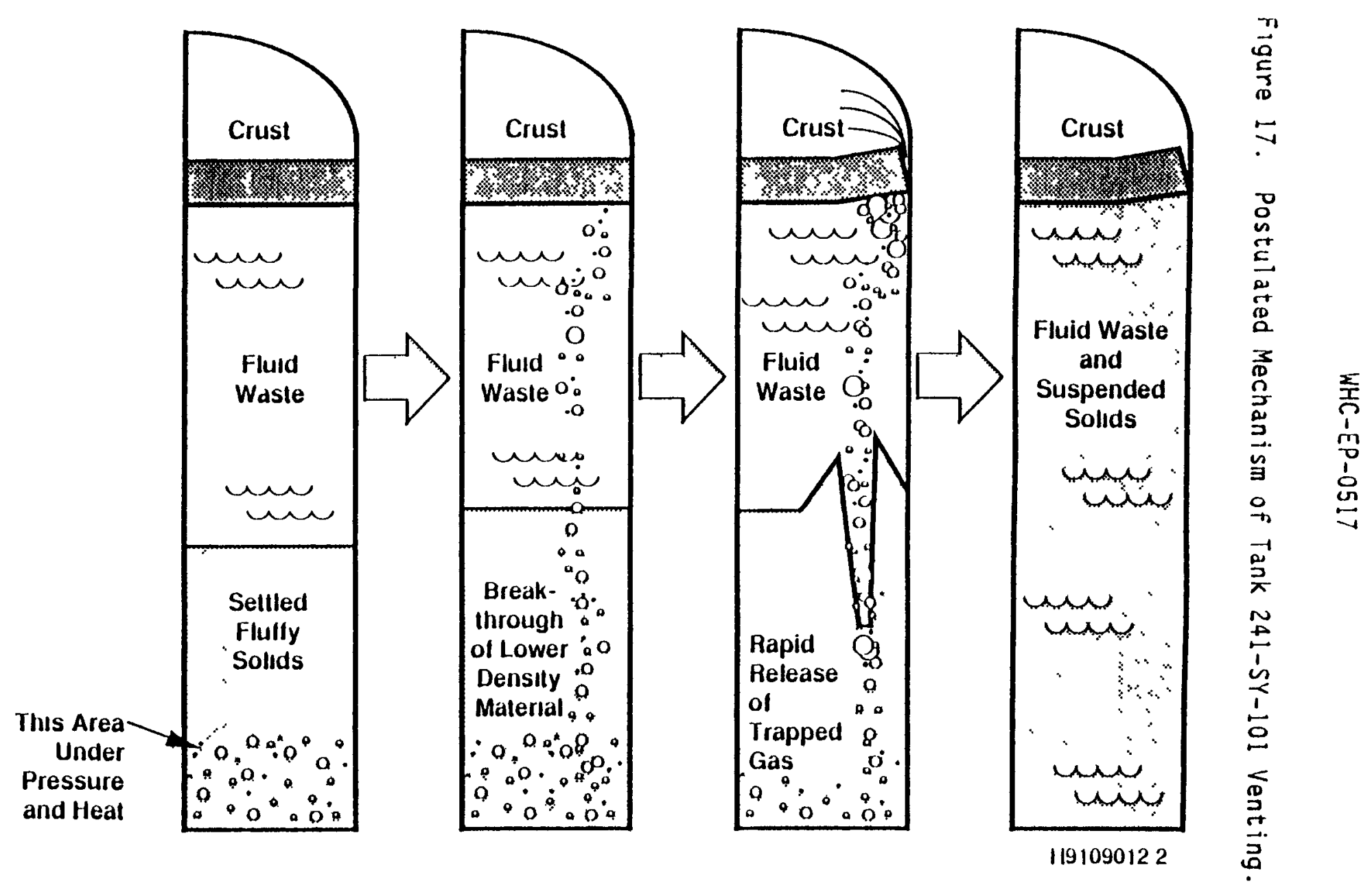




\subsection{THERMOCHEMICAL DEGRADATION}

\subsubsection{Background Information}

All of the gases released from Tank 241-5Y-101 have been observed in a series of studies that utilized synthetic double-shell slurry wastes in the absence of radiation. Gases that have been observed include $\mathrm{N}_{2} \mathrm{O}$ and $\mathrm{H}_{2}$, the most important gases from a safety aspect, as well as $\mathrm{N}_{2}$ and minor amounts of $\mathrm{CO}, \mathrm{CO}_{2}, \mathrm{CH}_{4}, \mathrm{NH}_{3}$, and $\mathrm{NO}_{x}$. While significant progress has been made in determining the chemical reactions responsible for generating these gases, it must be emphasized that the wastes in Tank 241-SY-101 are quite complex and that much work remains to be done.

The stoichiometry and rate of gas generation from synthetic wastes has been found to depend on waste composition, most notably nitrite, hydroxide, aluminate, and organic concentrations as well as organic identity. Delegard (1980) reported that gas generation occurred with HEOTA but not EDTA. The difference between these two chelating agents is that one of the carboxylate groups ( $-\mathrm{COOH})$ of EOTA is replaced by an alcohol group ( $-\mathrm{CH}, \mathrm{OH})$. Jansky and Meissner (1984) found similar behavior, reporting significani hydrogen generation when HEOTA and/or glycolic acid (hydroxyacetic acid) was present, but no gases generated in their absence. Delegard (1980) found that elimination of sodium aluminate from the synthetic waste composition substantially reduced the overall gas generation rate. This was recently corroborated by Ashby (1991). A first-order dependence on the hydroxide ion for concentrations below $1.5 \mathrm{M}$ was also reported (Delegard 1980). In these studies, wastes containing no sodium aluminate or no sodium nitrite were found to generate only very small quantities of gas; elimination of oxygen also drastically reduced gas generation rates. Elimination of sodium nitrate actually enhanced the rate of gas generation.

Chemical mechanisms responsible for the generation of gases are not well understood at this time, but considerable progress is being made. Reaction of a nitrate ion with sodium aluminum hydroxide dihydrate in the presence of HEOTA to form a nitro-hydroxyaluminum-HEDTA complex has been described (Tank Waste Science Panel 1991), which leads to the formation of $\mathrm{N}_{2} \mathrm{O}, \mathrm{H}_{2}, \mathrm{CO}_{2}$, and EO3A. A series of mechanisins that may be responsible for the breaking of carbon-carbon and carbon-nitrogen bonds, and the formation of hydrogen, ammonia, and other products have been described by Ashby (in Strachan 1991). The Oppenauer oxidation mechanism can also be used to explain the reaction of HEDTA via an intermediate hydroxyaluminum complex to form $\mathrm{H}_{2}$. Cannizzaro-type reaction mechanisms have also been proposed as a means of generating $\mathrm{H}_{2}$. Verification that these or other mechanisms are corract is being pursued through careful identification of reaction products by NMR and other methods, and through the use of isotopic labels to show the source of the product gases.

\subsubsection{Comparison to Gas Generation in Tank 241-SY-101}

No clear agreement at this time among the synthetic waste studies exists as to the stoichiometry of gases generated from synthetic wastes, particularly for $\mathrm{N}_{2} \mathrm{O} / \mathrm{H}_{2}$ ratios. At least some of this behavior probably arises from the 
choice of experimental waste compositions and reaction temperatures. While $\mathrm{N}_{2} \mathrm{O}$ exceeded the concentration of $\mathrm{H}_{2}$ by more than a factor of 10 in the presence of sodium nitrite, $\mathrm{H}_{2}$ exceeded $\mathrm{N}_{2} \mathrm{O}$ concentrations by more than a factor of 6 in the absence of sodium nitrite (Delegard 1980). Jansky and Meissner (1984) al so found $\mathrm{H}_{3}$ concentrations to exceed that of $\mathrm{N}_{2} \mathrm{O}$ by more than a factor of 10 when sodium nitrite was present. In contrast to these results from synthetic waste studies, gas compositional data obtained from the October 24, 1990 event indicate that $\mathrm{N}, \mathrm{O}$ and $\mathrm{H}_{2}$ were present in approximately a 1:1 ratio (Barker 1991; Allemann 1991). It should be noted that the temperatures used in synthetic waste studies to accelerate the rates of reaction using small batches of synthetic waste are usually $100^{\circ} \mathrm{C}$ or greater, whereas actual tank temperatures are approximately $60^{\circ} \mathrm{C}$; this difference may have a substantial impact on the stoichiometry of gaseous products. At Argonne National Laboratory, studies conducted at room temperature showed that no gases were formed in the absence of radiation. However, non-negligible generation of $\mathrm{H}_{2}$ was detected by the same workers at $60^{\circ} \mathrm{C}$ in the absence of radiation.

The quantity of hydrogen generated by thermaliy driven chemical degradation reactions in synthetic wastes accounts for perhaps one-third of that generated in the actual tank. A comparison of gas production calculated on the basis of synthetic waste studies and estimates for Tank 241-SY-101 is included in Table 3 . Hydrogen generation rates from synthetic wastes of 0.0013 moles over a period of $500 \mathrm{~h}$ at $90{ }^{\circ} \mathrm{C}$ using a $500-\mathrm{mL}$ waste volume correspond to a rate of approximately 500 moles of hydrogen per day per million gallons of waste. Using an activation energy of $25 \mathrm{kcal} / \mathrm{mole}$ (Delegard 1980; Siemers, in Strachan 1991) to adjust this rate to the actual tank temperature of $60^{\circ} \mathrm{C}$, a rate of 20 moles of hydrogen per day per million gallons of waste is obtained. Obviously, this estimation is very sensitive to the activation energy used. A change in the activation energy by $1 \mathrm{kcal} / \mathrm{mole}$ (to 24 or $26 \mathrm{kcal} / \mathrm{mole}$ ) would alter the estimated hydrogen yield by nearly a factor of 5 at $60^{\circ} \mathrm{C}$. A similar treatment of preliminary $\mathrm{N}_{2} \mathrm{O}$ results from work being conducted by Pacific Northwest Laboratory leads to an estimate of 100 moles of $N_{2} O$ per day per million gallons of waste at $60^{\circ} \mathrm{C}$. This quantity is approximately twice the estimated rate of generation of this gas from the actual tank.

Experiments conducted at Argonne National Laboratory found an overall rate of gas generation from a reference synthetic waste composition of $0.13 \mathrm{~mL} / \mathrm{h}$ per $100 \mathrm{~mL}$ waste volume at $120^{\circ} \mathrm{C}$. Correcting that gas volume to $60^{\circ} \mathrm{C}$ using an activation energy of $25 \mathrm{kcal} / \mathrm{mole}$ yields a gas production rate of 55 moles of gas per day per million gallons of waste.

It must be emphasized that the above discussion is an estimate only of the quantity of gases that might be produced by thermally driven degradation reactions. Synthetic wastes used in these experiments were considerably less complex than actual wastes; speciation of the organic components in the actual waste has not been performed to date. To accelerate the rate of gas generation in the synthetic waste studies, reaction temperatures in the range of 90 to $120^{\circ} \mathrm{C}$ were used rather than the actual tank temperature of $60{ }^{\circ} \mathrm{C}$, requiring correction of the laboratory data to account for the activation energy. If such an estimation is to be valid, one must be certain that the reaction mechanisms do not change over the temperature range in question. 
Table 8. Comparison of Gas Generation in Synthetic Waste Studies with Estimates for Tank 241-5Y-101.

\begin{tabular}{|c|c|c|c|}
\hline & Moles $\mathrm{H}_{2} /$ day & Moles $\mathrm{N}_{2} \mathrm{O} /$ day & Comments \\
\hline Thermochemical & 20 & 100 & $\begin{array}{l}\text { Results at Pacific } \\
\text { Northwest Laboratory } \\
\text { were obtained at } 90^{\circ} \mathrm{C} \\
\text { and corrected to } 60{ }^{\circ} \mathrm{C} \\
\text { using an activation } \\
\text { energy of } 25 \mathrm{kcal} / \mathrm{mol}\end{array}$ \\
\hline Radiolytic & $2 !$ & 207 & $\begin{array}{l}\text { From studies at } \\
\text { Argonne National } \\
\text { Laboratory }\end{array}$ \\
\hline $\begin{array}{l}\text { Estimates for } \\
\text { Tank 241-SY-101 }\end{array}$ & 64 & 52 & $\begin{array}{l}\text { Based on a slurry } \\
\text { growth rate of } \\
0.11 \text { in./day } \\
\text { (Strachan 1991) and } \\
\text { vent gas analyses for } \\
\text { the october } 24,1990 \\
\text { event. }\end{array}$ \\
\hline
\end{tabular}

The cause for the discrepancy between $N, O$ yields estimated from synthetic waste studies and that estimated from actual tank data is not known. Gas releases from Tank 241-SY-101 have been found to contain approximately equimolar quantities of $\mathrm{N}_{2} \mathrm{O}$ and $\mathrm{H}_{2}$, while synthetic waste results generally show $\mathrm{N}_{2} \mathrm{O}$ to be present at concentrations 0 to 10 times greater than $\mathrm{H}_{2}$. Considerably more $\mathrm{N}, \mathrm{O}$ production is estimated from synthetic waste studies than is indicated by actual release data. One oossible explanation involves the solubility of $\mathrm{N}_{2} \mathrm{O}$, which is orders of magnitude greater than that of $\mathrm{H}_{2}$. This high solubility may provide a means for enhanced transport of this gas through the liquid relative to $\mathrm{H}_{2}$ and greater continuous release rates from the tank surface. Monitoring of $\mathrm{N}_{2} \mathrm{O}$ and $\mathrm{H}_{2}$ releases from Tank 241-SY-101 between release events would be valuable in establishing whether the above is important.

\subsection{GAS GENERATION DUE TO RADIOLYTIC PROCESSES}

\subsubsection{Background Information}

The gases $\mathrm{H}_{2}$ and $\mathrm{O}_{2}$ are produced by the radiolysis of water, but when the chemicals present in Tank 241-SY-101 are added, the yields of these gases are markedly altered, and other gaseous products result. In addition to $\mathrm{H}_{2}, \mathrm{~N}_{2} \mathrm{O}$ and $\mathrm{N}_{2}$ were also found. Oxygen has been observed in the absence of organic solutes but is consumed if organics are present. Other gases that are likely to be produced are $\mathrm{NH}_{3}$ and $\mathrm{CO}_{2}$. 
Other radiolysis products may be important in gas generation. Degradation products of the organic chelators may be important in thermal reactions. For example, the degradation product formaldehyde (and other molecules with $\mathrm{C}-\mathrm{H}$ bonds that are not in the $\alpha$ position to a carbonyl group) have been proposed as sources of thermally produced $\mathrm{H}_{2}$. Evidence exists that hydrogen peroxide, which is formed in the radiolysis of water, can also form hydrogen in simulated tank systems.

Hydrogen and $\mathrm{N}, \mathrm{O}$ are of principal importance with respect to Tank 241-SY-101. The sources of hydrogen in radiolysis are well known for aqueous solutions containing no organic material. Hydrogen can be formed by the direct dissociation of water as well as by reactions between the primary transient species $H^{*}$ and the solvated electron $\left(\varepsilon_{a q}{ }^{\circ}\right.$ ). Because of the nonhomogeneous nature of energy deposition by ionizing radiation, which results in very large local concentrations of these transient species, the latter reactions cannot be reduced to zero at attainable concentrations of scavengers. Direct dissociation of water cannot be affected by added scavengers. Nevertheless, concentrations of $\mathrm{NO}_{2}^{-}, \mathrm{NO}_{3}^{-}$, and $\mathrm{OH}^{-}$similar to those present in Tank 241-SY-101 do cause great reduction in the radiolytic yield of $\mathrm{H}_{2}$, and the effects of variation in the concentrations of these ions on the $\mathrm{H}_{2}$ yield can be predicted. The presence of organics causes an increase in the yield of $H_{2}$ due to the reaction of $H^{\circ}$ atoms to abstract $H^{\circ}$ from the organic, but the magnitude of this increase is limited by the aforementioned inorganic ions, primarily nitrite ions, that effectively compete for the $H^{\text {. }}$ atoms. The effects of other solutes on the $\mathrm{H}_{2}$ yield can be predicted if the reactivity of the solute with $\mathrm{H}^{\circ}$ atoms is known at high $\mathrm{pH}$. Prior knowledge concerning $\mathrm{N}_{2} \mathrm{O}$ is much less complete compared with $\mathrm{H}_{2}$, and the exact mechanism of $\mathrm{N}_{2} \mathrm{O}$ formation is not known; information given in Section 5.3 .2 summarizes that state of knowledge.

\subsubsection{Comparison to Gas Generation in Tank 241-SY-101}

Modeling calculations have been performed and experiments conducted at Argonne National Laboratory using a homogeneous, simulated waste solution. The radiolytic yields (G-values in molecules/100 eV of energy deposited) of gases produced were determined. Yields of $\mathrm{H}_{2}$ and $\mathrm{N}_{2} \mathrm{O}$ have been measured in solutions irradiated at 30 and $60{ }^{\circ} \mathrm{C}$ that contain $2.12 \mathrm{M} \mathrm{NaOH}, 1.30 \mathrm{M} \mathrm{NaAlO}$, $2.22 \mathrm{M} \mathrm{NaNO}_{2}$, and $2.79 \mathrm{M} \mathrm{NaNO}_{3}$ (a solution intended to mimic the tank solution and referred to as solution "p" below), and concentrations of various organics (e.g., EDTA, HEDTA, IDA) in the range of 0.1 to $0.2 \mathrm{M}$. Nitrogen and $\mathrm{O}_{2}$ were al so determined, but $\mathrm{N}_{2}$ was generally not detectable (see below) and the addition of organics reduced a small $G\left(O_{2}\right)$ from solution $P$ to zero. In fact, $\mathrm{O}_{2}$, initially present in test solutions, is consumed when organics are present. The other likely gaseous products that have not yet been confirmed or denied are $\mathrm{NH}_{3}$ and $\mathrm{CO}_{2}$.

The dependence of the yield of $\mathrm{H}_{3}$ on the organic material should depend on the concentration and reactivity of the $H$ atom with the organic material. In line with this finding, the G-values of $\mathrm{H}_{2}$ show a qualitative correlation with the number of $\mathrm{C}-\mathrm{H}$ bonds in the additive and a linear dependence on organic concentration. The $\mathrm{G}$-values of $\mathrm{H}_{2}$ and $\mathrm{N}_{2} \mathrm{O}$ are somewhat higher at the higher temperature. For $\mathrm{H}_{2}$, the increase is in the range of $40=30 \%$ for a variety of additives and conditions. The variability in yield could be due to 
differences in activation energy for the hydrogen abstraction reaction. For $\mathrm{N}_{2} \mathrm{O}$, the increases at $60^{\circ} \mathrm{C}$ are somewhat larger and generally fall in the range of $25 \%$ to $100 \%$. Because $60^{\circ} \mathrm{C}$ corresponds to the approximate temperature in Tank 241-SY-101, the G-values of $H_{2}$ and $N_{2} 0$ measured at $60^{\circ} \mathrm{C}$ will be discussed in the following paragraphs, unless otherwise noted.

Independent of dose or dose rate, the generation of $\mathrm{H}_{2}$ occurs with a $G$-value in the range .02 to .07 from solution $P$ containing concentrations of the organic chelators and their degradation products chosen to simulata Tank 241-5Y-101 wastes. This estimate of G-value is based both on G-values measured when well-controlled additions of organic chelators were made and the G-values measured on a solution that had been pre-irradiated to simulate the effects in Tank 241-SY-101. Nitrogen was observed with a G-value of 0.13 from pre-irradiated material, but $\mathrm{N}_{2}$ was not detected from radiolys is of other simulated waste solutions. Generation of $\mathrm{N}_{2} \mathrm{O}$ from solution "p" with added organics occurs much more efficiently, having a G-value of about 1 , a yield which does not appear to depend on dose or radiation intensity.

From these yields, $\mathrm{H}_{2}$ and $\mathrm{N}_{2} \mathrm{O}$ generation rates of $2.5 \times 10^{-9}$ and $3.6 \times 10^{-8}$ moles liter min ${ }^{-1}$, respectively, are determined for synthetic Tank 241-SY-101 wastes. A nonradiolytic yield of $\mathrm{H}_{2}$ at $50{ }^{\circ} \mathrm{C}$ of $1.3 \times 10^{-9}$ moles liter min $^{-1}$ has been observed in solution $P$ containing $0.17 \mathrm{M} \mathrm{IOA}$; this yield brings the total rate of $\mathrm{H}_{2}$ generation up to $3.8 \times 10^{-9}$ moles 1 iter $^{-1} \mathrm{~min}^{-1}$. Of course, apolication of these numbers to the tank is an approximation both because it is not clear that this approach is applicable to nonhomogeneous phases, and because only the approximate chemical composition of the material in the tank is known; specific organic species present in the waste are unknown. The yield of hydrogen will be strongly. dependent on the organic and $\mathrm{NO}_{2}{ }^{-}$concentration but only weakly on the $\mathrm{NO}_{3}{ }^{\circ}$ concentration.

From the above measurements, yields of 21 moles/day of $\mathrm{H}_{2}$ and 207 moles/day of $\mathrm{N}_{2} \mathrm{O}$ are predicted (see Table 8). To explain the quantity of $\mathrm{H}_{2}$ generated per day based on slurry growth data, a $\mathrm{H}_{2}$ production rate of approximately 64 moles/day and a $N_{2} O$ production rate of 52 moles/day are needed. Thus, the measured production rates lead to about one-third the $\mathrm{H}_{2}$ production observed and about four times the $\mathrm{N}_{2} \mathrm{O}$ observed. Whether the radiolytic yields from the nonhomogeneous phases are sufficiently different to explain these disparities remains to be determined. Hydrogen production from organic radicals catalyzed by particulates as a possibility.

The large $\mathrm{N}_{2} \mathrm{O}$ excess has not been explained from experiments done on homogeneous systems where the total dose is not sufficient to saturate the solutions in $\mathrm{N}_{2} \mathrm{O}$ or $\mathrm{H}_{2}$. One can speculate on physical or chemical mechanisms to explain the discrepancy. A physical mechanism whereby $\mathrm{N}_{2} \mathrm{O}$ is continually lost between release events at a much larger rate compared with $\mathrm{H}_{2}$ is conceivable. Such a speculative mechanism follows. If $\mathrm{N}_{2} \mathrm{O}$ is adsorbed much more strongly than $\mathrm{H}_{2}$ on particulate matter, a release event may not appreciably dislodge $\mathrm{N}_{2} \mathrm{O}$ relative to $\mathrm{H}_{2}$. Then, $\mathrm{N}_{2} \mathrm{O}$ generated after a release event would escape at a rate closer to its production rate because its adsorption sites would still be saturated, whereas the $H_{2}$ would be less likely to escape in this way because its adsorption sites would have been purged of $\mathrm{H}_{2}$ during the release event. A similar variant would be that the $\mathrm{N}_{2} \mathrm{O}$ is much less strongly bound, or not bound at all to the particles so that almost all 
of the $\mathrm{N}_{2} \mathrm{O}$ escapes during the time between events. This means that the gas measured in an event does not well reflect the total yield of the gas. Another alternative is the chemical reaction of the $\mathrm{N}_{2} \mathrm{O}$ with radicals and ions (e.g., $\mathrm{NO}_{3}^{2-}$ produced in the solution). A saturated solution of $\mathrm{N}_{2} \mathrm{O}$ in solution $?$ is approximately $1 M$, so radical lifetimes in the millisecond range would make such a mechanism possible. While no evidence exists in the experimental yields of $\mathrm{N}_{2} \mathrm{O}$ as a function of total dose, insufficient dose has been given to test samples to create sufficient $\mathrm{N}_{2} \mathrm{O}$ to saturate the solution.

Some information related to the mechanism of $\mathrm{N}_{2} \mathrm{O}$ formation has been obtained. Use of sodium glycolate as an organic additive still results in a substantial yield of $\mathrm{N}_{2} \mathrm{O}$ despite the fact that there is no nitrogen in glycolate. Also, the use of ${ }^{15} \mathrm{~N}-1$ abeled glycine as an additive results in $\mathrm{N}_{2} \mathrm{O}$ that contains a negligibie amount of ${ }^{5} \mathrm{~N}$. These observations show that the nitrogen originates from the inorganic constituents, even though the organic is necessary to produce $\mathrm{N}_{2} \mathrm{O}$.

\subsection{CONCLUSIONS}

The knowledge and understanding of the risks from the cyclic ventings of Tank 24l-SY-101 have been greatly enhanced because of the sampling and laboratory studies conducted in fiscal year 1991.

Additional instrumentation for evaluating the composition of the vented gases has led to an estimated composition that is mainly hydrogen, nitrogen, and nitrous oxide. Small amounts of ammonia and water vapor are also present. The concentration of hydrogen in the exhaust header on top of the tank is above the lower flammability limit in some of the gas release events, but it is at that value for only a short time. The total amount of gas released in these episodic events ranges from 3,000 to $9,000 \mathrm{ft}^{3}$. Similarly, the observed changes in the surface level of the waste range from 5 to 10 in. During a gas release event, the hotter waste from the bottom portion of the tank moves to the top; this movement has been postulated to be due to a density instability that results from the entrainment of the gas.

A major effort was initiated to understand the mechanisms that are involved in the production of the various gases. Studies are being conducted on synthetic waste mixtures to determine the radiolytic mechanisms for the production of hydrogen and nitrous oxide. These studies have shown that the $\mathrm{H}_{2}$ and $\mathrm{N}_{2} \mathrm{O}$ are produced in the synthetic wastes that contain various organic compounds, but the production rates do not match those inferred from the analysis of the gas release events. Laboratory studies are also being conducted to evaluate the production of gases by the thermochemical degradation of the various chelating agents. These organic compounds have most likely degraded into numerous (ca. 100) compounds, thus presenting a very complex mixture. Tests are being done to determine the amount and composition of gases produced as a function of time at various temperatures. Both oppenauer oxidation and Cannizzaro reaction mechanisms may be involved in the formation of hydrogen. 
In fiscal year 1992, the laboratory studies on the gas generation mechanisms will continue, and studies will also be conducted to gain insight on the processes responsible for gas retention and release.

\subsection{REFERENCES}

Allemann, R. T., 1991, Slurry Growth Gas Composition, WHC-SA-1216-FP, Westinghouse Hanford Company, Richland, Washington.

Babad, H, G. D. Johnson, D. A. Reynolds, and D. D. Stepnewski, 1991, Slurry Growth Gas Composition, WHC-SA-12!o-FP, Westinghouse Hanford Company, Richland, Washington.

Barker, J. J., 1991, Evaluation of October 24, 1990 Tank 241-5Y-101 Gas Release Event, WHC-SO-WM-PE-041, Westinghouse Hanford Company, Richland, Washington.

Burke, T. M., K. G. Carothers, S. M. Joyce, and A. L. Pajunen, 1991, Evaluation of April 19, 1990 Tank 24:-5Y-101 Gas Release Event, WHC-SO-WM-PE-039, Westinghouse Hanford Company, Richland, washington.

Carothers, K. G., T. M. Burke, and D. A. Reynolds, 1989, Evaluation of August 5, 1990, Tank 241-SY-101 Gas Reilease Event, WHC-SO-WM-PE-040, Westinghouse Hanford Company, Richland, Washington.

Delegard, C., 1980, Laboratory Studies of Complexed Waste Slurry Volume Growth in Tank 241-SY-101, RHO-LD-124, Rockwell Hanford Operations, Richland, Washington.

Jansky, M. T., and B. A. Meissner, 1984, Latter to L. M. Sasaki, "Proposed Laboratory Experiment to Study High-Temperature Decomposition of Complexants," Letter No. 65453-84-071, Rockwell Hanford Operations, Richland, Washington.

Strachan, 0. M., 1991, Minutes of the Tank Waste Science Panel Meeting February 7-8, 1991, PNL-7709, Pacific Northwest Laboratory, Richland, Washington.

Tank Waste Science Panel, 1991, Chemical and Physical Processes in Tank 241-5Y-101: A Preliminary Report, PNL-7595, Pacific Northwest Laboratory, Richland, Washington. 


\section{DISTRIBUTION LIST}

Number of Copies

\section{OFFSITE}

10

U.S. Department of EnerqyHeadquarters
J. C. Tseng

2

Argonne National Laboratory/

Chemistry Division

9700 South Cass Avenue

Argonne, I1lino is 60439-4831

E. P. Horwitz

D. Meisel

1

Carnegie-Mellon Universityl

Chemical Engineering Design

Science Incoroorated

163 Witherow Road

Sewickley, Pennsylvania 15143

G. Powers

1

The Florida State Universityl Department of Chemistry

Tallahassee, Florida 32306

G. R. Choppin

1

Georgia Institute of Technology 225 North Avenue Boggs Chemistry Building

Atlanta, Georgia 30332

E. C. Ashby

3
A. Schneider
5005 Hidden Branches Drive
Dunwoody, Georgia 30338 
DISTRIBUTION (continued)

Number of Cooies

2

Hazards Research Corporation 200 Valley Road

Mt. Arlington, New Jersey 07856

C. Grelecki

W. W. Schulz

727 Sweetleaf Orive

Wilmington, Delaware 19808

1

Lawrence Livermore National Laboratory

P.0. Box 808, L-22!

Livermore, California 94550

8. Hudson

2

Los Alamos National Laboratory

P.0. Box 1663, MSC 920

Los Alamos, New Mexico 87545

S. F. Agnew

T. Larson

D. Oakley

3

Science Apolications International

J. O. Bunting

R. Daniels

H. Sutter

2

Oak Ridge National Laboratory P.0. Box 2008, MS 6268

Oak Ridge, Tennessee 37831-6268

0. 0. Campbel1

T. Kress

1

Sandia National Laboratory

P.0. Box 5800

Albuquerque, New Mexico 87185

S. Slezak.

Distr-2 
OISTRIBUTION (continued)

Number of Copies

1

Rice University

5211 Paisley

Houston, Texas 77096

A. S. Veletos

2

Massachusetts Institute of Technology Department of Nuclear Engineering 77 Massachusetts Ave., Room 24-109 Cambridge, Maryland 02139

C. Forsberg

M. Kazimi

1

Harvard University 295 Upland Avenue Newton Highlands, Maryland 02161

M. First

1

Air Products \& Chemicals. Inc. 7201 Hamilton Blvd

Allenton, Pennslyvania 18195-1501

G. Schmauch

1

C. Abrams

1987 Virginia

Idaho Fali's, Idaho 83404

1

F. Carlson

6965 North 5th West

Idaho Falls, Idaho 8340 I

1

LOS Al amos National Laboratory

409 12th Street, SW, Suite 310

Washington, OC 20024-2188

D. Oakley 
DISTRIBUTION (continued)

Number of Copies

1

University of Washinaton 1 Chemistry Department Building 10

Seattle, Washington 98195

B. R. Kowalski

1

Vanderbilt University

P.0. Box 1596, Station 8

Nashville, Tennessee 37235

F. L. Parker

1

Washington State University/ Department of Chemical Engineering Pullman, Washington 99164

W. J. Thomson

Westinghouse Savannah River Company Box 616

Building 773A, Room B132

Aiken, South Carolina 29802

N. Bibler

\section{ONSITE}

U.S. Department of Energy Field Office, Richland

G. J. Bracken

A4-02

R. F. Christensen

A4-02

J. M. Clark

A4-02

R. E. Gerton

A4-02

J. P. Hamric

W. A. Rutherford

A7 -32

Publ ic Reading Room (2)

A4-02

A1-65 


\section{DISTRIBUTION (continued)}

\section{Number of Copies}

R. T. All emann

$K 7-15$

S. A. Bryan

PT -25

J. A. Campoell

P8-08

T. H. Dunning

$K 2-18$

B. M. Johnson

$K I-78$

M. R. Kreiter

$\mathrm{K} \sigma-35$

G. B. Mellinger

PT -18

L. R. Pederson

$\mathrm{K} 2-44$

D. M. Strachan

$\mathrm{K} 2-38$

D. S. Trent

$K]-82$

Westinghouse Hanford Company

J. C. Allen-Floyd

H4-23

T. M. Anderson

83-01

H. Babad (5)

W. B. Barton

M. L. Bell

J. D. Berger

R. M. Black

R. J. Blanchard

$\mathrm{H} 4-23$

L4-75

H4 -23

LO- 18

R. J. Bliss

RI-19

J. W. $8100 m$

R! -17

B3-04

D. C. Board

$55-15$

D. M. Bogen

$51-57$

M. T. Bouchey

SO- 09

S. C. Bradley

R2-40

T. M. Burke

83-06

E. J. Campoell

$\mathrm{HO}-34$

R. J. Cash

B3-30

S. C. Chang

G. M. Christensen

$\mathrm{H} 4-23$

$\mathrm{HO}-34$

W. L. Cowley

J. L. Deichman

$\mathrm{H} 4-23$

H5-31

$\mathrm{H} 4-23$

G. T. Dukelow

$\mathrm{H} 4-23$

C. W. Dunbar

R1-30

G. L. Dunford

$55-15$

J. A. Eaker

L. E. Eyre

X. A. Gasper

S. D. Godfrey

A. W. Graves

D. G. Hamrick

C. E. Hanson

$R 1-51$

RI-5I

H4-23

R1-51

H5- 1

R1-51

H. O. Harmon

H5- 09

D. L. Herting

$R 2-52$

T6-50 


\section{DISTRIBUTION (continued)}

R. C. P. Hill

H4 -23

R. D. House

R2-83

M. N. Is I am

R1-49

J. Jo

G. D. Johnson (10)

R2-11

N. W. Kirch

W. L. Knecht

H4 -23

M. K. Korenko

R2-11

E. J. Kosiancic

$\mathrm{HO}-34$

B3-08

SO-61

J. A. Lechelt (5)

R2-11

W. D. Leggett

L7 -03

S. Marchetti

R2-50

R. M. Marusich

H5-32

S. J. Mech

G. J. Miskho

D. J. Newland

L7-06

R2-50

A. F. Noonan

$54-55$

R2-12

D. M. Ogden

HO-34

R. S. Pooielarczyk

RI-30

R. W. Powell

P. R. Praetorius

$\mathrm{H} 4-14$

J. G. Propson

R2-56

$R 2-18$

R. E. Raymond

RI-80

I. E. Reep

O. A. Reynolds (5)

H4-23

C. P. Schroeder

R2-11

L7 -06

L. K. Severud

H5-60

M. H. Shannon

H5-30

D. D. Stepnewski

H5-32

J. D. Thomson

RI -30

R. E. Vandercook

R2-50

$O$. L. Wegener

R. K. Welty

A. E. Wilder

G. R. Wilson

D. D. Wodrich

RI-62

RI-80

RI-51

H4 -23

R2 -23

W. F. Zuroff

Information Release (3)

R2-14

H4- 17

Central Files 